\title{
Hudobný portrét Doriana Graya v opere Ĺubice Čekovskej
}

\author{
Ivana Lacková
}

\section{Úvod}

Stále aktuálna otázka krásy ludského tela a jej konfrontácie s duševnou skazenostou človeka je témou knižného diela Portrét Doriana Graya. Nadčasový a známy príbeh cieli na najvnútornejšie ludské úzkosti a zároveň najhlbšie túžby. Pôvodné dielo írskeho dekadentného' básnika a spisovatela viktoriánskej doby Oscara Wilda je ponurým románom o ludskej márnivosti a deštrukcii ludskej duše. Jednou zo základných tém diela je posadnutost' mladostou, krásou a následný strach z ich postupnej straty. Zaoberá sa rozporom medzi pôžitkom z krásy a morálkou. Literárne dielo Portrét Doriana Graya v sebe ukrýva filozoficko-estetické úvahy o sile umenia, ktoré môže svojho autora a prijímatela povznášat', ale rovnako aj devastovat'. ${ }^{2}$ Táto variácia faustovskej legendy ${ }^{3}$ spôsobila v dobe svojho vydania škandál a bola odsúdená za prvky hedonizmu. ${ }^{4}$

Dňa 8. a 9. novembra 2013 uviedlo Slovenské národné divadlo premiéru opery slovenskej skladatel'ky Ĺubice Čekovskej. Román Portrét Doriana Graya ju oslovil natol'ko, že sa kontroverznú tému rozhodla spracovat’ ako hudobnú drámu.

\section{Oscar Wilde a jeho román Portrét Doriana Graya}

Dej románu sa odohráva vo viktoriánskom Anglicku v 19. storočí. V tomto období panovala královná Viktória, ktorej vláda trvala od roku 1837 až do jej smrti v roku 1901. Práve počas vlády královnej Viktórie zažilo Anglicko najväčší hospodársky a ekonomický rozkvet. Patrilo medzi najmocnejšie krajiny na svete. Viktoriánska doba bola obdobím modernizácie nielen v oblasti vedy a technológie, ktorá l’ud’om výrazne ulahčila prácu, ale rovnako aj modernizácie volebného systému a väčšej slobody názorov a náboženstva. Anglicko riadené aristokraciou a cirkvou sa zmenilo na obchodnú a priemyselnú spoločnost', ktorá sa postupne stala demokratickou. Napriek tomu, že viktoriánske Anglicko žilo v blahobyte, mier bol každoročne narúšaný vojnovým stavom. 
V rámci viktoriánskej literatúry boli v popredí diela písané v próze, najväčší rozkvet zaznamenal román. Práve ten ponúkal otvorené možnosti na diskusiu o politických, filozofických či sociálnych témach. Autori prostredníctvom románu často prezentovali svoje názory na aktuálnu dobu. ${ }^{5} \mathrm{Na}$ začiatku viktoriánskej doby sa rozvinul literárny smer kritický realizmus a stal sa dominantnou charakteristikou románu až do roku $18800^{6}$

Za najrozšírenejší prejav kritického realizmu možno považovat’ sociálny román. Účelom sociálno-kritického románu je čo najvernejšie zobrazit’ spôsob života, všetky spoločenské vrstvy a rozdiely medzi nimi.? Za najvýznamnejšieho spisovatel'a viktoriánskej literatúry sa považuje Charles Dickens.

Súčastou literatúry bola vo vel'kej miere dekadencia. Diela dekadentných spisovatelov boli pesimistické, spracúvali sa témy ako násilie, strach, zlo či satanizmus. Hlavní hrdinovia literárnych diel často porušovali a odmietali morálne a estetické normy. Ciel'om bolo vzbudit' u čitatel'a strach a pohoršenie. ${ }^{8}$ Medzi popredných dekadentných spisovatel'ov možno zaradit' práve Oscara Wilda.

\section{Život a dielo Oscara Wilda}

Oscar Wilde, vlastným menom Oscar Fingal O'Flahertie Wills Wilde, sa narodil 16. októbra 1854 v Írskom Dubline. Pochádzal z troch detí. Jeho rodičia boli uznávaní intelektuáli. Oscarov otec, William Wilde, bol vychýreným oftalmológom, lekárom král'ovnej Viktórie. Jeho matka, Jane Francesca Elgeeová, úspešná spisovatel'ka, bola známa pod pseudonymom Speranza. Oscar Wilde študoval klasickú filológiu na prestížnej škole Trinity College v Dubline a neskôr na Magdalen College v Oxforde. Patril medzi najlepších študentov. Už počas štúdia získal mnoho významných ocenení (ocenenie The Berkeley Gold Medal for Greek, cena Newdigate Prize za študentskú báseň Ravenna). Univerzitní profesori John Ruskin a Walter Pater mali na Wildovu d’alšiu tvorbu nepopieratel'ný vplyv. Oscar Wilde bol prísnym estétom, sarkastikom a kritikom spoločnosti. Odmietal spoločenské predpisy a požiadavky, ktoré by umelcovi odopierali možnost' vyjadrit’ sa.

V roku 1879 v Londýne ukončil štúdiá a naplno sa začal venovat’ písaniu. Už o dva roky neskôr, v roku 1881, vydal svoju prvú básnickú zbierku pod názvom Poems [Básne] a prvú divadelnú hru s názvom Vera. V roku 1882 odcestoval z Londýna do New Yorku, kde viedol sériu prednášok o estetike a estetickom cítení. Vrátil sa do Anglicka a rozhodol sa pre d’alšie prednáškové turné v Anglicku a Írsku. Stal sa popredným zástupcom estetického hnutia a v roku 1891 publikoval zbierku esejí Intentions [Intencie], v ktorej využíva princípy estetizmu. Wildov estetizmus bol do značnej miery ovplyvnený dielom Studies of the Greek Poets [Štúdie gréckych básnikov] z pera anglického literárneho kritika a poetu Johna Addingtona Symondsa. Vplyv na jeho estetiku mali aj klasické texty Aristotela a Platóna. Wilde považoval za synonymum slova estetizmus krásu bez limitov. Podla neho túži každý jedinec po kráse a neštastný je ten, kto ňou nedisponuje. ${ }^{9}$

Dnes sa jeho meno spája s mnohými divadelnými hrami, medzi tie najznámejšie patria napríklad The Decay of the Art of Lying, The Truth of Masks, The Critic as Artist, Lady Windermere's Fan [Vejár lady Windermerovej], The Importance of Being Earnest [Aké dôležité je mat' Filipa] a Woman of No Importance [Bezvýznamná žena], či The Soul of Man Under Socialism [Duša človeka zo socializmu]. Známa je aj jeho dráma Salome, ktorá sa stala podkladom pre rovnomennú operu Richarda Straussa. Nemalú pozornost' venoval aj detskej literatúre. Napísal niekol'ko bájok pre deti, modernú zbierku rozprávok The 
Happy Prince and Other Tales [Štastný princ a iné príbehy], ktorú publikoval v roku 1888. Pod vplyvom dánskeho dramatika, rozprávkara a básnika Hansa Christiana Andersena vydal zbierku príbehov House of Pomegranates [Dom granátových jabĺk]. V súčasnosti ho však najväčšmi charakterizuje jeho jediný román The Picture of Dorian Gray [Portrét Doriana Graya].

Celý život Oscara Wilda ovplyvňovala homosexualita. Napriek svojej orientácii bol ženatý a mal dve deti. Wildovou celoživotnou láskou však nebola jeho manželka, ale mladý lord Alfred Douglas. Na základe žaloby Douglasovho otca sa po odsúdení za sodomiu dostal na dva roky do väzenia, kde vykonával t’ažké práce. Jeho manželka sa s ním rozviedla a spolu s det’mi sa odstáahovala do Švajčiarska. Po prepustení z väzenia žil Wilde v chudobe. Pod novým menom - Sebastian Melmoth - opustil Anglicko, bez peňazí cestoval po Európe a býval v najlacnejších hoteloch.

Zomrel 30. novembra 1900 vo veku 46 rokov na chronický zápal ucha, ktorý prešiel do zápalu mozgových blán. Skonal v parížskom hoteli d'Alsace. Pochovali ho na cintoríne v Bagneux, avšak v roku 1909 boli jeho pozostatky premiestnené na parížsky cintorín Père-Lachaise. ${ }^{10}$

\section{Vznik a vydanie románu}

Portrét Doriana Graya, v originálnom anglickom znení The Picture of Dorian Gray, bol vo svojej prvotnej forme publikovaný v júni 1890 ako novela v časopise Lippincott's Monthly Magazin. Wildov predslov k textu neskôr publikovali samostatne v prominentnom magazíne Fortnightly Review. Prvotná verzia novely bola kritikmi odsúdená za hedonizmus a šírenie homosexuality. Do roku 1861 bola sodomia - jedno z označení pre sexuálny kontakt medzi mužmi - trestaná smrtou a po zmene zákona doživotným väzením. ${ }^{11}$ Wilda tak prepadli obavy, že by za toto svoje dielo mohol byt' odsúdený. Napriek tomu sa pôvodnú novelu rozhodol prepracovat’ na román. Rozšíril ho o predslov zložený z radu aforizmov, ktoré sa pokúšali odpovedat’ na niektoré z kritík pôvodného príbehu. ${ }^{12}$ Predslov možno rovnako chápat' ako vlastnú autorovu obhajobu diela:

„Všetko umenie predstavuje zároveň povrch aj symbol. Tí, čo sa ponárajú pod povrch, robia tak na vlastné nebezpečenstvo. Tí, čo sa usilujú pochopit'symboly, robia tak na vlastné nebezpečenstvo. Rozmanitost' názorov na umelecké dielo dokazuje, že dielo je nové, mnohotvárne, živé. Ked'sa názory kritikov rozchádzajú, umelec je $v$ súlade sám so sebou."13

Do románu Wilde pridal šest’ nových kapitol a v dôsledku spoločenského tlaku odstránil časti, ktoré výrazne hovoria o homosexuálnej láske. V apríli 1891 londýnske vydavatel'stvo Ward Lock \& Co vydalo prepracovanú verziu diela v knižnej podobe. Ani prepracovaná verzia sa úspechu nedočkala, rovnako ako prvá verzia bola odsúdená kvôli homosexualite a hedonizmu.

\section{Inšpirácie k vzniku románu Portrét Doriana Graya}

Anglická historička Fiona MacCarthyová tvrdí, že Dorian Gray nie je fiktívna postava. Podla nej je inšpirovaný krásou anglického spisovatela Johna Graya, člena Wildovho literárneho homosexuálneho kruhu. ${ }^{14}$ Wilde sa s ním stretol v roku 1889 v dome dizaj- 
nérov Charlesa Rickettsa a Charlesa Shannona. Podla viacerých dostupných zdrojov boli dlhé roky milencami.

Bloger Andrew Martin, venujúci sa otázkam súvislostí medzi literárnymi dielami, konštatuje, že hlavná Wildova inšpirácia vychádzala z básne Roberta Browninga My Last Duchess. Báseň je príbehom vojvodu, ktorý zo žiarlivosti zabije svoju manželku a po jej smrti si necháva namal'ovat' portrét jej tváre. Obraz ukrýva na mieste, ktoré je dostupné len jemu. Téma vraždy, ktorú sám vykoná, a ukrytého portrétu jeho manželky, spája báseň My Last Duchess s románom Portrét Doriana Graya. Podla Andrewa Martina bol Oscar Wilde už ako malý chlapec vel'kým obdivovatel'om Roberta Browninga. Svoje prvé kópie básní Wilde venoval Browningovi s pod’akovaním za radost', ktorú mu už od detstva prinášali jeho básne. ${ }^{15}$ Za Wildovu inšpiráciu možno považovat’ aj hororový román Melmoth the Wanderer spisovatel'a Charlesa Roberta Mathurina, strýka Wildovej matky. Prítomný je v ňom faustovský motív, ked'hlavný hrdina rovnako ako Dorian Gray zapredá svoju dušu v túžbe po večnej kráse. ${ }^{16}$

Za d’alšiu Wildovu inšpiráciu možno považovat' jeho matku, Jane Francescu Agnes - Lady Wilde. Z pôvodného anglického jazyka preložila do francúzštiny gotický hororový román Wilhelma Meinholda Sidonia the Sorceress, ktorý Wilde už ako malý chlapec s nadšením čítal. Román v sebe ukrýva temné, pochmúrne prostredie a tajomstvá - to sú prvky nielen uvedeného románu, ale i literárnych diel spisovatelov ako Edgar Allan Poe, Charles Baudelaire či Bram Stoker. Wilde ich diela čítal, a tak je možné, že Portrét Doriana Graya je inšpirovaný aj nimi. Inšpiráciou mu s najväčšou pravdepodobnostou boli aj Sonnets [Sonety] anglického spisovatela, dramatika a herca Williama Shakespeara venované neznámemu mužovi. ${ }^{17}$ Portrét Doriana Graya bol v širšom zmysle ovplyvnený aj viktoriánskou dobou, v ktorej Wilde žil a ktorú sme charakterizovali vyššie.

Z hladiska inšpirácie možno hovorit' aj o historickej postave menom Dandy. Dandy je historický termín pre opis osoby, ktorá venuje prílišnú pozornost' svojmu vzhliadu. Často sa považuje za štandard mužskej krásy. V minulosti určoval Dandy módny trend. Dandy sa ako človek v mnohých smeroch líši od ostatných členov spoločnosti nielen svojím vzhladom, ale aj svojimi zvykmi a spôsobmi: má vynikajúcu reč, pedantské spôsoby, je sebavedomý a miluje stát pred zrkadlom. ${ }^{18}$ Praví predstavitelia „dandyizmu“ venovali osobitú pozornost' hygiene. Ich oblečenie bolo vždy čisté a voňavé. Košele a rukavice si vyžadovali dôkladnú starostlivosț. Pre skutočných „dandies" tu bolo nevyslovené pravidlo: za týždeň by mal človek vymenit’ asi dvadsat’ košiel', tridsat’ vreckoviek, pätnást' druhov nohavíc, viac ako tridsat' kravát a nekonečné množstvo ponožiek. ${ }^{19}$ Oscar Wilde bol tiež Dandy a aj viaceré literárne postavy jeho diel svojou charakteristikou pripomínajú postavu Dandyho: Dorian Gray, Lord Henry (Portrét Doriana Graya), Lord Goring z Wildovho diela An Ideal Husband a tiež postava Algernon (dielo The Importance of Being Earnest).

\section{Stručná charakteristika románu}

Portrét Doriana Graya je napísaný v „er-forme“.20 Dej románu pozostáva z dvadsiatich kapitol, ktoré nie sú označené názvom. Udalosti nasledujú chronologicky za sebou, dej nenarúšajú iné línie, príbehy či udalosti. Autor v diele kládol dôraz na zmyslové vnímanie, využil často prikrášlený, umelecký a opisný jazyk, ktorým sa oslobodil od spoločenských konvencií a ktorý mu umožnil vytvorit’ špecifické umelecké dielo. Za- 
meral sa na opis vôní, farieb, umelecký opis prírody. Jeho cielom bolo prinútit' čitatel'a vnímat’ danú situáciu zmyslami, vychutnat’ si jej krásu, zažit’ potešenie, až potom sa na situácie a veci pozerat' s rozumom.

Dielo sa nesie v duchu dekadencie a estetizmu, ktorého hlavnou prioritou bol život vyplnený krásnymi skúsenost’ami, pretože krása je sama osebe dobrá. Román obsahuje hororové prvky a faustovskú tematiku. Dielo má filozofické črty: prináša dlhé príhovory o pohl'ade na svet a spoločnost', kritiku spoločnosti a zosmiešnenie členov jej vyšších vrstiev.

\section{Charakteristika postáv}

Dorian Gray je ústrednou postavou celého románu. Je zázračne pekný, má jemne vykrojené červené pery, belasé oči a kučeravé zlaté vlasy. ${ }^{21} \mathrm{~V}$ jeho tvári je všetka vrúcnost' a čistota mladosti. Na začiatku príbehu vystupuje ako mladý aristokrat prostej a ušl'achtilej povahy, čistá a nepoškvrnená duša. Vedie bezstarostný život, stále je však nezrelý a neskúsený. Ked' mu maliar Basil ukáže dokončený portrét jeho tváre a lord Henry mu opakuje, aký je krásny a aká je krása pominutel'ná, Dorian sa začne obávat efemérnosti svojho pôvabu a mladosti.

Vyslovuje túžbu po večnej mladosti a kráse:

„Aké je to smutné. Ja zostarnem a budem strašný a odporný. Ale tento obraz ostane vždy mladý. Nikdy nebude starší ako práve v tento júnový deň... Keby to len bolo naopak! Keby som ja mohol ostat' navždy mladý a tento obraz keby starol! Za to za to - dal by som všetko! Áno, všetko, všetko na svete by som za to dal! Dal by som za to aj svoju dušu! Mladost' je to jediné, čo má pre človeka význam. Ked'zbadám, že starnem, zabijem sa."22

Henry Wotton má na Doriana značný vplyv a začína formovat’ jeho osud. Stačí len chvíla, aby sa Dorianov pohlad na svet pod vplyvom lorda Henryho zmenil. Henry mu ukazuje spôsob života, ktorý nepozná nudu a v ktorom sa pokušenia dá zbavit’ jedine tým, že mu človek podlahne. Dorian začína žit’ podl'a životnej filozofie Henryho, dokonca ju neskôr sám propaguje. Zapríčiní samovraždu svojej bývalej snúbenice. Jeho smútok však netrvá dlho. Nad’alej žije spoločenským životom, je členom spoločenských klubov, ba dokonca sám vo svojom dome organizuje večierky. Postupom času začne Dorian pôsobit’ na svojich blízkych podobne ako lord Henry na Doriana. Všetku svoju energiu vynakladá na zvelad’ovanie svojej krásy, stáva sa z neho sebecký muž zahl'adený predovšetkým do seba. Jeho čistá duša sa mení na monštrum, ktoré je schopné aj zabíjat'. Po vražde Basila a Jamesa Vana začína Dorian prehodnocovat’ svoj život. Uvedomuje si, aký hrozný vplyv mal na neho Henry a aké strašné veci napáchal. Zmierený s osudom sa rozhodne skončit' s minulost'ou a očistit' sa.

„Vie, že sa zhanobil, naplnil mysel' skazenostou a fantáziu hrôzou. Vie, že mal zlý vplyv na druhých a že mu to spôsobilo ukrutnú bolest'. Vie, že ludské životy, práve tie najkrajšie a najslubnejšie, ktoré mu prišli do cesty, priviedol do hanby. Niet preňho už nádeje? ?'23 $^{\prime 23}$

"Ked'vošli, našli na stene visiet'skvelý portrét svojho pána, ako ho naposledy videli, v plnej nádhere zázračnej mladosti a krásy. A na dlážke ležal mŕtvy muž v smokingu, 
s nožom v srdci. Mal zvädnutú, zvráskavenú, odpudzujúcu tvár. Iba ked'mu prezreli prstene na rukách, spoznali, kto to bol.'24

Lord Henry Wotton je šlachtic, inteligentný muž a očarujúci rečník. Často sa objavuje na londýnskych večierkoch vyššej anglickej spoločnosti a navštevuje divadlo. Kritizuje moralizmus a pokrytectvo viktoriánskej spoločnosti. Jeho základnou životnou filozofiou je myšlienka hedonizmu. Neustále upozorňuje Doriana na jeho krásu, ktorá je podla neho obrovským darom.

„Mladost' je to najcennejšie, čo človek môže mat. Máte zázračne krásnu tvár. Áno, pán Gray, bohovia boli k vám štedrí. Ale čo bohovia dajú, rýchlo aj berú. Máte iba zopár rokov na ozajstný, dokonalý a plný život. Ked'sa mladost' pominie, pominie sa aj krása. Budete hrozne trpiet'... Ach, užívajte mladost', kým ju máte..25

Henry pretvorí celú Dorianovu osobnost', nabáda ho „odolávat" pokušeniu tým, že mu podlahne. Lord Henry nerozlišuje, čo je správne a čo je nesprávne. Koná tak, ako to cíti, bez ohl'adu na to, aké následky môžu mat’ jeho slová a činy.

„Sme trestaní za svoje odolávanie. Každý impulz, ktorý sa usilujeme potlačit, pretrváva v duši a kvapká do nej jed. Jediný spôsob, ako sa zbavit' pokušenia, je podlahnút' mu. Odolajte mu a duša vám ochorie túžbou po tom, čo si sama zakázala."26

Basil Hallward je umelec, autor portrétu Doriana Graya a dlhoročný priatel' lorda Henryho. Ich povahy sú však diametrálne odlišné. Basil je dobrosrdečný a milý človek, zarytý idealista, veriaci v dobro ludstva. Hned' na úvod deja opisuje Henrymu, ako sa zoznámil s Dorianom, a z jeho slov je citel'né, že sa do neho zamiloval už pri ich prvom stretnutí.

„Ked’sa nám oči stretli, cítil som, ako blednem. Zmocnil sa ma zvláštny pocit strachu. Vedel som, že stojím zoči-voči človeku, ktorý by bol schopný ovládnut' svojou prítažlivostou celú moju bytost', celú moju dušu, samo moje umenie, ak by som to pripustil. Bol by som neštastný, keby som ho nevidel každý deň. Nemôžem sa bez neho zaobíst.' Dorian Gray je pre mňa proste umeleckým motívom. Ty v ňom možno neuvidiš nič. Ja v ňom vidím všetko. On je teraz pre mňa celým mojím umením. ${ }^{27}$

Dorian je jeho najväčšou inšpiráciou. Basil tvrdí, že ked'je Dorian pri ňom, dokáže vytvorit’ skutočné majstrovské dielo. Je očarený jeho krásou a pôvabom. Basil sa mladého aristokrata už od začiatku deja snaží upozornit', aby si nenechal ovplyvnit’ názory a svoje myslenie lordom Henrym. Počas celého príbehu sa Basil ukazuje ako starostlivý priatel', ktorý má o Doriana skutočný strach. Snaží sa ho naviest' na správnu cestu, vymanit' ho spod zlého vplyvu Henryho, prosí Doriana o modlitby. Zomiera zdesený pohladom na zdevastovanú dušu Doriana Graya, ktorú odhaluje jeho portrét.

Sibyl Vanová je mladá, krásna a talentovaná herečka. Pochádza z chudobnej rodiny, žije so svojou matkou, starou herečkou, a svojím bratom Jamesom Vanom. Až dovtedy, kým nestretne Doriana Graya, je umenie jej jedinou vášňou. Láska Sibyl Vanovej k Dorianovi je čistá, úprimná a verná. Verí v lásku na celý život, v manželstvo a ich spoločné štastie. Dorianovo opovrhnutie a následný odchod v nej vyvolá zúfalstvo. Dorian pre ňu znamená celý svet a bez neho jej život d’alej nemá zmysel. 
„Dorian, kým som t’a nepoznala, hrat divadlo bolo jedinou náplňou môjho života. Iba v divadle som žila. Bola som Rosalindou jeden večer a Porciou druhý. Verila som vo všetko. Dnes večer, prvý raz v živote, videla som plytkost', faloš, hlúpost' prázdnej parády, v ktorej som vždy hrala. Dnes večer prvý raz som si uvedomila, že Rómeo je škaredý a slová, ktoré som mala hovorit', sú neskutočné, neboli to moje slová. Priniesol si mi čosi vyššie, čosi, čoho je všetko umenie iba odrazom. Pomohol si mi pochopit', čo je láska. Láska moja! Čarovný princ!"28

James Vane je bratom Sibyl Vanovej. Je námorníkom a väčšinu času trávi mimo domu. Je starostlivý a milujúci, za každých okolností bojujúci o bezpečie svojej sestry a matky. Správa o sestrinej smrti ho zlomí a zaprisahá sa zabit' Doriana tak, ako slúbil. Prenasledovanie Doriana sa mu však stane osudným.

Pani Leafová a Viktor sú oddanými Dorianovými sluhami, pracujúcimi v dome už niekol'ko desat'ročí. Sú láskaví a starostliví.

\section{Opera Dorian Gray}

Dorian Gray v spracovaní slovenskej hudobnej skladatel'ky L’ubice Čekovskej a libretistky Kate Pullingerovej je opera v troch dejstvách, členená do šestnástich obrazov, písaná v anglickom jazyku. Príbeh, zaoberajúci sa otázkami fyzických a duchovných podôb krásy a zla, je založený na dualite vnútra a zovňajšku, rozpráva o túžbe po večnej mladosti a kráse, deštrukcii ludskej duše, márnivosti a chamtivosti. Námet berie z románu Oscara Wilda Portrét Doriana Graya. Náznaky homosexuality a „faustovské" zapredanie duše hlavného hrdinu, túžiaceho po večnej kráse a mladosti, možno označit’ ako provokatívne polohy, ktoré sa do značnej miery vzd’alujú tradičným témam slovenskej opernej tvorby.

Svetová premiéra opery Dorian Gray sa uskutočnila 8. a 9. novembra 2013 v historickej budove Slovenského národného divadla v Bratislave v rámci medzinárodného festivalu súčasnej hudby World New Music Days 2013 a festivalu Melos-Étos. Inscenačný klúč opernej inscenácie Dorian Gray mal pôvodne vytvorit’ známy anglický režisér David Pountney, ten však z pracovných dôvodov nemohol ponuku prijat'. Dielo napokon zinscenovala jeho manželka Nicola Raabová, ktorú možno zaradit’ k mladšej generácii medzinárodne etablovaných operných tvorcov. O hudobné naštudovanie sa postaral Christopher Ward, anglický dirigent s pozitívnym vzt’ahom k súčasnej hudbe. Scénu a kostýmy pre opernú inscenáciu navrhli kostýmové výtvarníčky a scénografky Alexandra Burgstallerová a Anna Marie Legensteinová. Skladatel'ka si pôvodne priala, aby postavu Doriana Graya stvárnil slovenský tenorista Pavol Bršlík. Pre pracovnú vyt’aženost' však ponuku neprijal a hlavnú postavu nakoniec stvárnil americký tenorista Eric Fennel a írsky tenorista Eamonn Mulhall. ${ }^{29}$

\section{Skladatel'ka a libretistka Ĺubica Čekovská}

Slovenská hudobná skladatel'ka a klaviristka Ĺubica Čekovská patrí k najvýraznejším talentom svojej generácie. Narodila sa 16. marca 1975 v Humennom. Jej otec, Marián Čekovský, bol klaviristom, jej matka, Eva Mudráková, výborná speváčka. Profesionálne sa venovali populárnej hudbe a už počas socializmu chodievali hrávat’ do Nórska a Švédska. 
„Pri klavíri sa u nás sedelo v jednom kuse, vela sme spievali. Nájst' si na klavíri melódie som vedela už ako malé dievčatko, otec mi robil k lavej ruke dvomi rukami harmonické sprievody. Bol úžasný a výnimočný muzikant. ${ }^{130}$

Ĺubica sa už odmalička spolu so svojím bratom, slovenským hudobníkom, spevákom, skladatelom a komikom Mariánom Čekovským, pohybovala vo svete hudby, ktorá bola prirodzenou súčastou ich rodiny. Už počas navštevovania základnej umeleckej školy v odbore hra na klavíri jej bola bližšia improvizácia a hra podla sluchu, než hra z nôt. Po skončení gymnázia sa rozhodla pre štúdium hudobnej teórie na Vysokej škole múzických umení v Bratislave v triede Juraja Beneša. Práve on do značnej miery ovplyvnil hudobné smerovanie Čekovskej a nabádal ju na štúdium kompozície, ktorú napokon vyštudovala v triede Dušana Martinčeka. O oboch profesoroch sa v súčasnosti mladá skladatel'ka vyjadruje ako o vel'kých hudobných a ludských inšpiráciách. V rokoch 1998 - 2000 absolvovala postgraduálne štúdium na londýnskej Royal Academy of Music (RAM) u Paula Pattersona. Po skončení štúdia na RAM pokračovala vo svojom hudobnom vzdelávaní v mnohých kompozičných kurzoch. V septembri roku 2010 sa stala rezidenčnou skladatel'kou programu Composer in Residence v Gere v Nemecku. Jej diela sa uvádzali na významných festivaloch súčasnej hudby ako napríklad: festival Spitalfields v Londýne, festival Melos-Étos v Bratislave, Festival Davida Oistracha v Pärnu v Estónsku a mnoho d’alších. K jej oceneniam patria: Cuthbert Nunn Composition Prize of the Royal Academy of Music (1998) za skladbu Fragment a elégia pre sólový bajan, Leverhulme Award (1999), Elsie Owen Prize (1999) od Royal Academy of Music a Štipendium ISH od jej veličenstva královnej Alžbety. ${ }^{31}$ Hudobný fond jej v roku 2005 udelil Cenu Jána Levoslava Bellu za dielo Piano Concerto (Two Portraits) [Koncert pre klavír a orchester (Dva portréty)]. L’ubica Čekovská je autorkou mnohých komorných, symfonických, inštrumentálnych a vokálnych diel, komponuje tiež scénickú a filmovú hudbu. Od roku 2008 do roku 2018 bola členkou umeleckej rady prestížneho hudobného festivalu Pražská jar. Do roku 2013 pôsobila tiež ako pedagóg na Katedre skladby a dirigovania VŠMU. Dlhé roky bola klaviristkou v orchestri Bratislava Hot Serenaders. Od roku 2020 vyučuje kompozíciu na Hudobnej a umeleckej akadémii Jána Albrechta v Banskej Štiavnici. V súčasnosti ju zastupuje renomované nemecké vydavatel'stvo Bärenreiter-Verlag v Kasseli.

Medzi autorkine najnovšie diela možno zaradit' Koncert pre husle a orchester, Theatre Music pre sláčikový orchester, suita Dorian Gray, Evenood pre dychové kvinteto, Four Movements pre klavír. ${ }^{32}$

Dorian Gray je Čekovskej prvým celovečerným operným dielom, ale nie jej prvou hudobnodramatickou kompozíciou. Tou bol kolektívny skladatel'ský projekt As Time Goes By realizovaný pre Štátnu operu Hannover (2005).

Kate Pullingerová sa narodila v Britskej Kolumbii v meste Cranbrook. Strednú školu vyštudovala na Vancouverskom ostrove. Po roku a pol na McGrill Univerzite v Montreale zanechala štúdium literatúry a filozofie a odišla pracovat' do medenej bane $v$ Kanade. Za zarobené peniaze sa rozhodla cestovat'. Usadila sa v Londýne, kde žije doteraz. V súčasnosti sa venuje printovej a digitálnej produkcii, scenáristickej tvorbe a vo viacerých inštitúciách pôsobí ako rezidenčná autorka. ${ }^{33}$ Pracuje tiež ako profesorka kreatívneho písania a digitálnych médií na Bath Spa University, kde je súčasne riaditel'kou centra pre výskum v oblasti kultúrneho a kreatívneho priemyslu. 
Medzi jej známe diela patria romány Landing Gear, A Little Stranger, Weird Sister, The Last Time I Saw Jane, Where Does Kissing End? či digitálna fikcia Breath. Do jej tvorby možno zaradit' aj zbierky poviedok My Life as a Girl in a Men's Prison a Tiny Lies. ${ }^{34} \mathrm{~V}$ roku 2009 získala za svoj román The Mistress of Nothing prestížnu kanadskú cenu Governor General's Literary Award for Fiction. V roku 2014 získala cenu Anne Green Award at Wordfest. $V$ tom istom roku spolupracovala so spisovatelom a divadelným tvorcom Neilom Bartlettom na vytvorení digitálneho vojenského denníka Letter to an Unknow Soldier. V roku 2019 bola nominovaná do užšieho výberu na cenu New Media Writing Prize. To, čo Kate Pullingerovú najviac preslávilo, je jej román Piano. Podla neho bol natočený rovnomenný film v réžii Jane Campionovej, na ktorom Kate Pullingerová pracovala ako spoluautorka. V apríli roku 2020 vyšiel jej najnovší román Forest Green. ${ }^{35}$

\section{Okolnosti vzniku opery Dorian Gray}

Ked'v roku 2009 dostala slovenská hudobná skladatel'ka L’ubica Čekovská ponuku od bývalej generálnej riaditel'ky Slovenského národného divadla Silvie Hroncovej a jej spolupracovníka Rolanda Tótha na napísanie opery, prijala ju ako výzvu. ${ }^{36}$ Predstavy o tematike pripravovaného hudobno-dramatického diela boli rozmanité. Jedným zo základných kritérií bolo nájst’ silný námet, ktorým by podla Čekovskej opera mala disponovat'. Uvažovala o dekadentných námetoch ako The Pit and the Pendulum [Jama a kyvadlo] od Edgara Allana Poea či La Peau de chagrin [Šagrénová koža] od Honoré de Balzac. Po diskusii s manželovou matkou, Martou Malachovskou, vol'ba nakoniec padla na kultové dielo írskeho spisovatela Oscara Wilda The Picture of Dorian Gray [Portrét Doriana Graya]. Silvia Hroncová návrh na námet opery schválila. Pre skladatel'ku toto dielo znamenalo skvelý východiskový materiál:

„Snažili sme sa zachovat' všetko, čo k nemu patrí - nejde len o príbeh samotný, ale aj o to, že táto kniha bola vo svojej dobe velmi kontroverzná; ...Boli tu skrátka silné a podnetné momenty, ktoré si žiadali mnoho premýšlania. ${ }^{137}$

Podla skladatel'ky je téma Doriana Graya vel'mi aktuálna:

„Na začiatku je to vel'mi čistý človek, obdarený krásou, no počas príbehu sa vplyvom ludí mení, prepadá sa aj spoločensky, až to končí drámou. ${ }^{138}$

Pavol Smolík sa vo svojom článku s názvom L’ubica Čekovská: Dorian Gray k téme opery vyjadruje nasledovne:

„Dnešná doba [...] je plná klamných obrazov. Tejto tendencii výdatne napomáha rozvoj médií, ktoré sú zväčša fabrikou na ,falošné portréty.' Svet je plný ludí, ktorí si ,tvár nechali doma' - a namiesto pozitívneho budovania vlastnej identity sa prezentujú koženou maskou pekných, sympatických a úspešných, naučenou na imidžmejkerských školeniach. ${ }^{\prime 39}$

Libretistku Kate Pullingerovú sa rozhodlo oslovit' nemecké vydavatel'stvo Bärenreiter Publishing. ${ }^{40}$ Vedenie Slovenského národného divadla poskytlo skladatel'ke a libretistke niekol'ko stretnutí. Počas nich diskutovali o tom, čo z príbehu Doriana Graya vypustit', a naopak, čo treba zachovat'. Spoločne sa zhodli, že opera bude postavená na akomsi dualizme dobra a zla, krásna a škaredosti, alebo mravného podsvetia a sveta anglickej vyššej spoločnosti. ${ }^{41}$ 
„Moju úlohu libretistky ulahčila čistota a krása Wildovho štýlu. Dorian Gray, opera, ktorú sme spolu so skladatel'kou vytvorili, skúma tému dualizmu ludskej prirodzenosti. Dorianov príbeh lakomstva, spupnosti a narcizmu predstavuje silný odkaz pre dnešok s našou kultúrou posadnutosti mladým zovňajškom, bohatstvom a krásou."142

Čekovská i Pullingerová považovali za mimoriadne dôležité príbeh zachovat’ v pôvodnom jazyku. Angličtina sa im zdala ideálna pre Doriana Graya aj napriek tomu, že podl'a Čekovskej je „... vel'mi tažkým jazykom na zhudobňovanie a má špecifický rytmus i melódiu reči, čo determinuje podobu hudobných viet." ${ }^{43}$ Čekovská dbala aj o vysokú úroveň prekladu libreta do slovenčiny. Vedenie SND oslovilo slovenskú prekladatel'ku Janu Kantorovú-Bálikovú. Do procesu písania libreta zasiahol aj operný režisér David Pountney, ktorý skladatel'ke a libretistke navrhol vykonat' drobné zmeny založené na princípe divadla $v$ divadle. Taktiež prišiel s návrhom rozrušit’ monolitný textový tok Baudelairovými veršami a monológom Shakespearovej Ofélie, či priniest’ dramaturgický kontrast zaradením Tureckého tanca. ${ }^{44} \mathrm{~V}$ hotovom librete pomohol skladatel'ke pri hudobno-sylabickej práci. ${ }^{45}$ Následná komunikácia skladatel'ky a libretistky prebiehala cez internet a v nejednom rozhovore Čekovská uviedla, že ich spolupráca bola vel'mi koncentrovaná a intenzívna. Kým Kate Pullingerová písala libreto, Čekovská ho pripomienkovala a korigovala.

Od objednávky vtedajšieho vedenia Slovenského národného divadla z roku 2009 až po premiéru sa opera rodila takmer štyri roky. Hudobná kompozícia zabrala Čekovskej dva a pol roka:

„Ja som sa do komponovania tohto diela zamilovala a išlo to pomerne bez nejakých komplikácií, ale pamätám sa, že niektoré scény som niekol'kokrát prepisovala, pokial'som našla to pravé."146

Atmosféra príbehu bola pre skladatel'ku hudobnou inšpiráciou:

„Hudobne som operu postavila na takom dualizme, povedzme ,pekna' a,škaredna. Nápady mi prichádzali postupne. Nazhromaždila som si mnoho nápadov a potom som ich selektovala. Ked'niečo komponujem, počujem to rovno vo farbách v orchestri. Myslím si, že pri písaní tejto opery som nebola až tak príliš moderná, pretože to asi ani nie som ja, ale pridržiavam sa tradície, s pohladom do budúcnosti, ale takým svojím vlastným spôsobom, ktorý mi je blízky." ${ }^{47}$

Postavy a ich hlasové zaradenie

\begin{tabular}{|l|l|}
\hline Postava & Hlasové zaradenie \\
\hline Dorian Gray & tenor \\
\hline Lord Henry Wotton & barytón \\
\hline Basil Hallward & basbarytón \\
\hline Sybil Vane ${ }^{48}$ & soprán \\
\hline Mrs. Leaf & mezzosoprán \\
\hline Bordelmama & mezzosoprán \\
\hline James Vane & barytón \\
\hline Alan Campbell & tenor \\
\hline
\end{tabular}


Dej opery

Prvé dejstvo, scéna prvá: Dej sa začína vo farebnej a svetlej pracovni maliara Basila, ktorý dokončuje svoje životné dielo - portrét Doriana Graya. Lord Henry ospalo leží na pohovke a maliar Basil stojí pred nedokončeným portrétom Doriana. Lord Henry je z obrazu nadšený, tvrdí, že obraz Doriana Graya je najlepším dielom Basila a bezpochyby ho musí poslat' Akadémii. ${ }^{49}$ Basil mu oznamuje, že obraz nezverejní, ani nikam nepošle - dal doň príliš mnoho zo seba samého. Spomína si na prvé stretnutie s Dorianom, počas ktorého ho mladý aristokrat očaril do takej miery, že sa rozhodol namal'ovat' jeho obraz. Vtom zaznieva zvonec a do miestnosti vchádza Dorian Gray. Je mladý a krásny. Maliar Basil ho zoznamuje so svojím starým známym, lordom Henrym. Obaja si vymenia pohlady a je jasné, že medzi nimi prebehla iskra. Maliar Basil požiada Henryho, aby odišiel. Chce konečne dokončit' svoje dielo - Dorian však Henryho prosí, aby ostal. Zatial' čo Basil dokončuje svoj obraz a Dorian Gray pózuje, lord Henry filozofuje o živote, pokušení a potešení. Dorian mu rozpráva o svojej túžbe zabávat’ sa. Henry mu odpovedá, že ak sa chce zbavit' pokušenia, musí sa mu poddat'. Basil vycíti Henryho zámer a prosí Doriana, aby ostal taký, aký je, a nenechal sa ovplyvnit'. Obraz je hotový - všetci traja pred ním stoja a obdivujú ho. Obdivujú nielen portrét, ale i krásu a mladost' Doriana. Mladý Gray sa na obraz nevie vynadívat'. Vyslovuje túžbu ostat’ navždy mladým a krásnym výmenou za svoju dušu.

Scéna druhá: Druhá scéna je situovaná do lacného londýnskeho divadla. Dorian Gray tam vstupuje oneskorene, po začatí hry. Na javisko prichádza Sibyl Vane, mladá a chudobná herečka, stvárňujúca postavu Ofélie zo Shakespearovej hry Hamlet. Obecenstvo búrlivo tlieska. Dorian je unesený jej krásou a schopnost’ami. Po skončení hry uteká do zákulisia, aby sa s mladou herečkou zoznámil.

Scéna tretia: Dorian vstupuje do šatne Sibyl Vane, hovorí jej komplimenty. Ona je vzrušená a štastná, teší sa z jeho obdivu. Zamiluje sa do neho. Dorian ju požiada, aby sa stala jeho manželkou. Sibyl nadšene súhlasí. Dorian odíde a na scénu prichádza James Vane, herečkin brat. Sibyl mu oznamuje, že sa bude vydávat’ za muža, ktorého meno dosial' nepozná. Hovorí mu o jeho kráse, je si istá, že s ním bude v bezpečí. James je neistý, rozhodnutie svojej sestry pokladá za nesprávne a nezodpovedné. Vyhlasuje,že ak jej mladý muž ublíži, zabije ho.

Scéna štvrtá: Dorian Gray, lord Henry a Basil navštevujú divadlo s úmyslom vidiet’ Sibyl Vane. Dorian im oznamuje, že sa s ňou ožení. Presviedča Henryho o svojej láske k Sibyl, celý svet je vraj pre neho ničím v porovnaní s ňou. Henry sa zasmeje a nesúhlasne sa pozrie na Basila. Maliar uverí Dorianovým citom, láska mu podla neho pridáva na kráse. Lord Henry ostáva nepokojný a rozladený. Do svetla reflektorov vojde Sibyl, spieva tú istú áriu, ktorou po prvýkrát očarila Doriana. Tento raz je však neistá, jej spevácky aj herecký výkon vyznieva rezignovane. Dorian je šokovaný, Sibyl hrá chladne a bez citu, rezignuje na umenie. Lord Henry hovorí Dorianovi, že láska je len napodobovanie, rovnako ako jej herecký výkon. Spolu s Basilom odchádza do klubu. Dorian ostáva v divadle do konca hry. Predstavenie sa končí chabou odozvou, Sibyl sa pokloní a odíde z javiska. Rozladený Dorian sa prediera do šatne mladej herečky.

Scéna piata: Ked'Dorian vstúpi do šatne, je arogantný a agresívny, jeho slová sú trpké a kruté - svojím zlým výkonom ho Sibyl ponížila pred jeho priatel'mi. Napriek tomu 
je št’astná, už viac nechce hrat'. Umenie sa jej v porovnaní s láskou zdá smiešne. Láska k Dorianovi pre ňu znamená ovel'a viac, snaží sa ho pobozkat'. Dorian ju však od seba odstrčí a s nenávist’ou jej tvrdí, že bolo hlúpe a bláznivé lúbit' ju. Sibyl je znepokojená a vystrašená. Dorian chce odíst', už viac netúži po jej dotykoch a láske. Sibyl ho však prosí, aby ostal a neopúštal ju. Dorian jej znovu pripomenie, akú hanbu a poníženie mu spôsobila, už ju nikdy nechce vidiet'. Odchádza. Sibyl padne na zem a plače. „Vezmem si t’a, budem ti ženou. Svet sa zmenil, pretože si učinený zo zlata a slonoviny," znejú jej posledné slová. Vypije jed a zomiera.

Scéna šiesta: Divák sa ocitá v londýnskom dome Doriana. Mrs. Leaf, verná domáca pani Doriana Graya, pribieha s listom od lorda Henryho. Dorian však list ignoruje a prizná sa jej, aký bol krutý. Ona ho upokojuje, vraj nemôže byt' krutý, pretože ho všetci milujú. Dorian ju posiela preč. Osamote lutuje svoje slová, ktoré povedal Sibyl, chce jej napísat' list. Vyruší ho však príchod znepokojeného lorda Henryho. Dorian sa mu spovedá zo svojej chyby, chce íst' za Sibyl. Ked' sa od neho dozvie o smrti mladej herečky, bolestivo vykríkne. Lord Henry ho upokojuje, že napriek tomu, že sa jej smrt’ bude vyšetrovat', Sibyl nepoznala jeho meno, takže on nebude mat' problémy. Dorian je zúfalý. Podíde k obrazu, zastaví sa pred ním. Oplakáva smrt’ Sibyl, neustále opakuje, že ju zabil. Dorian zist’uje, že sa obraz zmenil. Pochopí, že ostane navždy mladý a portrét bude starnút. Zapredal svoju dušu.

Druhé dejstvo, scéna siedma: O osemnást' rokov neskôr v londýnskom dome Doriana Graya. Stále rovnako mladý a krásny Dorian leží na gauči, číta knihu, ktorú mu dal lord Henry. Mrs. Leaf privádza Henryho. Ten si všíma Dorianovo zaujatie knihou a konštatuje, že knihy nie sú morálne či nemorálne, ale len dobre alebo zle napísané. Do domu vchádza vysoký mladý muž, Alan Campbell. Dorian sa jeho prítomnosti teší. Campbell so sebou privádza prekvapenie - mladého chlapca, odetého do tradičných tureckých šiat. Chlapec tancuje, Dorian a Alan nadšene tlieskajú.

Scéna ôsma: Odohráva sa v ópiovom brlohu. Dorian, lord Henry a Alan Campbell sa prechádzajú po vel'kej chudobnej časti Londýna. Vstupujú do verejného domu, kde je nevestinec i ópiový brhol. Opilstvo, sex, hazardné hry a ópium. Na to všetko dohliada bordelmama, ktorá si troch bohatých mužov prehliada očami. Dorian flirtuje s bordelmamou. Tá ho schladí slovami, že za svoju zmluvu s diablom zaplatí, a že nie je hoden jej pozornosti. Nasleduje dražba prostitútov a l'ahkých žien, ktorých môžu klienti získat’ pre zábavu. Počas nej ponúka lord Henry vysoké sumy, aby ich aspoň na jednu noc mohol vytiahnut’ z „pekla“. Dražbu napokon vyhráva Dorian a výhru si delí napoly s Alanom. Henry odchádza a Dorian napĺña slová, ktoré mu pred pár rokmi lord Henry vštepoval: „Jediný spôsob, ako sa dá zbavit’ pokušenia, je podlahnút'mu."

Scéna deviata: Opät’ sa ocitáme v salóne Dorianovho domu. Čaká ho tam Basil a pani Leafová sa prechádza po dome. Basil sa jej pýta, kedy príde Dorian. Tá mu odpovedá, že má svoj vlastný čas a chodí, kedy sa mu zachce. Basil si znovu pripomína, čo všetko vložil do svojho portrétu Doriana Graya. Ked'Dorian konečne prichádza, Basil ho informuje o tom, čo sa o ňom hovorí. Dorian ho prijíma s nevôlou, z jeho prítomnosti nie je nadšený. Nikto si nevie vysvetlit’ Dorianovu stále mladú tvár a krásu. Vraj má vplyv na každého, s kým sa bližšie spozná. Basil chce verit', že klebety, ktoré o ňom ludia šíria, nie sú pravda, a túži poznat' jeho dušu. Dorian ho volá do hornej časti domu, kde má ukrytý „denník svojej duše”. 
Scéna desiata: Dorian prikazuje vystrašenému Basilovi, aby odhrnul záves. On odmieta, záves odhŕňa sám Dorian. Za ním sa skrýva zohavený portrét Doriana Graya. Dorian berie nôž, prebodne maliara a Basil umiera.

Scéna jedenásta: Dorian prichádza spät do salónu a vystrašený budí Mrs. Leaf. Posiela ju, aby okamžite priviedla Alana Campbella. Píše list a zatvára ho do obálky. Ked'Alan príde, Dorian sa mu priznáva k svojmu ohavnému činu a prosí ho, aby mŕtve telo Basila premenil na popol. Alan to urobit’ odmieta, Dorian sa mu preto vyhráža kompromitujúcim listom, ktorý má pripravený do novín pre prípad, že by mu Alan nechcel vyhoviet. Alan tak nemá na výber.

Scéna dvanásta: Dorian pošle Alana do podkrovia. Hádže mu lekársku kabelu a zatvára dvere. Alan ostáva s mŕtvym telom Basila sám.

Tretie dejstvo, scéna trinásta: Dorian Gray sa opät’ nachádza v nevestinci. Tento raz je však nepokojný, rozrušený a odtláča ženy a mužov, ktorí sa ho usilujú pokúšat'. Dorian si začína uvedomovat', že jeho duša umiera. Chce zabudnút'. Rozpráva sa s bordelmamou. V kúte miestnosti sedí James Vane. Ked' začuje meno Dorian Gray, vstane od stola a mieri k Dorianovi. Obviňuje ho zo samovraždy jeho sestry. Dorian sa tvári, že ju nikdy nepoznal. Ked' James zbadá jeho mladú, krásnu tvár, ospravedlní sa mu. Bordelmama však Jamesovi prezradí, že Dorian zapredal dušu diablovi v túžbe po večnej mladosti a kráse.

Scéna štrnásta: Divák sa znovu ocitá v Dorianovom dome, kde domáci pán hostí skupinku ludí. Chodí po miestnosti a svojim hostom spieva. Hostia zdvorilo tlieskajú, väčšine však ide iba o alkohol. Dorian si v speve pripomína Henryho ponaučenia. Na večierok prichádza mladá speváčka, v ktorej Dorian vidí Sibyl. Dorian sa jej pýta, či si ho vezme za muža, ona však uniká a vytratí sa z domu. Prichádza Henry a Dorianovi zvestuje správu o samovražde Alana Campbella. Dorian ho však nevníma. Neustále opakuje životné poučky: „Vyliečit’ si dušu vd’aka svojim zmyslom a vd'aka duši vyliečit' si zmysly." V okne sa objavuje James Vane, ktorého si všimne len Dorian. Je zdesený a vystrašený. Počuje spev Sibyl Vane. Chytá ho úzkost' z hrôzy zomierania. Snaží sa presvedčit’ samého seba, že mu žiadne nebezpečenstvo nehrozí, že iba blúzni. Zvonku sa ozýva krik ludí. Mrs. Leaf prichádza a oznamuje, že vonku zrazil koč istého muža. Jeho mŕtvolu prinášajú do Dorianovho domu, ten $v$ ňom spoznáva Jamesa Vana, ale pred ostatnými to neprizná. Rozhodne sa všetko ukončit'.

Scéna pätnásta: V podkrovnej izbe stojí Dorian pred svojím ohavným portrétom. Chce ho zničit'. Na stole je ešte stále položený nôž, ktorým zavraždil Basila. Chce zabit’ svoju minulost’ a bodá do obrazu. Sám však mučivo vykríkne a zomiera.

Scéna šestnásta: Mrs. Leaf prichádza v smútočnom odeve do podkrovnej miestnosti, ktorá je čistá a prázdna. Roztvára závesy a do tmavej miestnosti vpúšta svetlo. 


\section{Komparácia libreta a románovej predlohy - odlišnosti}

\begin{tabular}{|c|c|}
\hline Román & Libreto \\
\hline $\begin{array}{l}\text { V prvej kapitole rozpráva maliar Basil lordovi } \\
\text { Henrymu podrobný príbeh o tom, ako sa } \\
\text { zoznámil s Dorianom Grayom. Dorian je pre } \\
\text { Basila najväčšou inšpiráciou a Basil tvrdí, že } \\
\text { Dorian je pre neho celým svetom. Je zrejmé, } \\
\text { že sa Basil do Doriana zamiloval. }\end{array}$ & $\begin{array}{l}\text { Basil svoje zoznámenie sa s mladým aristokra- } \\
\text { tom lordovi Henrymu neopisuje. Dorian je pre } \\
\text { Basila skôr len inšpiráciou a priatel'om. Vztahah } \\
\text { Basila a Doriana je v librete neutrálnejší ako } \\
\text { ten v predlohe. }\end{array}$ \\
\hline $\begin{array}{l}\text { Dorian spolu s Henryho ženou lady Viktóriou } \\
\text { vedie rozhovor o hudbe. }\end{array}$ & $\begin{array}{l}\text { V librete sa manželka lorda Henryho - lady } \\
\text { Viktória - neobjaví. }\end{array}$ \\
\hline $\begin{array}{l}\text { Dorian rozpráva Henrymu, že ked' po prvýkrát } \\
\text { vstúpil do divadla, videl Sibyl v úlohe Júlie zo } \\
\text { Shakespearovej hry Rómeo a Júlia. }\end{array}$ & $\begin{array}{l}\text { Ked'Dorian Gray prichádza do divadla po prvý- } \\
\text { krát, Sibyl hrá úlohu Ofélie zo Shakespearovej } \\
\text { hry Hamlet. Spieva dlhý monológ Ofélie. }\end{array}$ \\
\hline $\begin{array}{l}\text { Zoznámenie sa Sibyl Vane a Doriana Graya } \\
\text { prebehne len cez opis, ktorý poskytne Dorian } \\
\text { lordovi Henrymu. }\end{array}$ & $\begin{array}{l}\text { Zoznámenie sa Sibyl Vane a Doriana Graya } \\
\text { prebieha počas dlhého dueta plného zamilo- } \\
\text { vaných slov. }\end{array}$ \\
\hline $\begin{array}{l}\text { Sibyl Vane nadšene oznamuje svojej matke, že } \\
\text { sa zamilovala. Ona ju upozorňuje, že dôležitej- } \\
\text { šie ako láska sú peniaze na splatenie dlhov. }\end{array}$ & V librete nie je zmienka o matke Sibyl. \\
\hline $\begin{array}{l}\text { Ked' Dorian Gray prichádza do divadla v spo- } \\
\text { ločnosti Basila a Henryho, Sibyl deklamuje } \\
\text { úryvok z monológu Júlie. }\end{array}$ & $\begin{array}{l}\text { Ked' Dorian Gray prichádza do divadla v spo- } \\
\text { ločnosti Basila a Henryho, Sibyl deklamuje } \\
\text { úryvok z monológu Ofélie. }\end{array}$ \\
\hline $\begin{array}{l}\text { V pôvodom diele má Dorian Gray dvoch slu- } \\
\text { hov - Viktora a pani Leafovú. }\end{array}$ & V librete je Dorianovou slúžkou iba Mrs. Leaf. \\
\hline $\begin{array}{l}\text { Dorian volá Alana Campbella do svojho domu } \\
\text { s prosbou, aby odstránil mŕtve telo Basila. } \\
\text { Z diela sa o ich predošlom vztahu dozvedáme } \\
\text { len tol'ko, že boli blízkymi priatel'mi. Ich priatel'- } \\
\text { stvo sa však z neuvedeného dôvodu skončilo. } \\
\text { Alan Campbell nechce mat's vraždou nič spo- } \\
\text { ločné. Dorian sa mu vyhráža prezradením jeho } \\
\text { tajomstiev, a tak Alan nemá na výber a musí } \\
\text { Dorianovi pomôct'. }\end{array}$ & $\begin{array}{l}\text { Alana Campbella pozýva do Dorianovho } \\
\text { domu lord Henry. Alan prichádza v sprievode } \\
\text { mladého chlapca, ktorý je tanečník. Spoločne } \\
\text { odchádzajú do nevestinca s úmyslom zabávat' } \\
\text { sa. Po vražde Basila posiela Dorian Mrs. Leaf za- } \\
\text { volat' Alana Campbella. Rovnako ako v románe } \\
\text { nie je ani v librete uvedený dôvod, prečo sa ich } \\
\text { priatel'stvo skončilo. Dorian sa Alanovi vyhrá- } \\
\text { ža. Alan tak nemá na výber a musí Dorianovi } \\
\text { pomôct' odstránit' mŕtve telo Basila. }\end{array}$ \\
\hline $\begin{array}{l}\text { V románe vystupuje žena prezrádzajúca } \\
\text { Jamesovi Vanovi Dorianovo tajomstvo len } \\
\text { vel'mi krátko. Dorian Gray a žena z baru spolu } \\
\text { dialógy nevedú. }\end{array}$ & $\begin{array}{l}\text { V librete je touto ženou bordelmama. Dorian } \\
\text { s ňou vedie dialóg dvakrát, dokonca s ňou } \\
\text { flirtuje. Bordelmama ho rovnako ako Sibyl } \\
\text { Vane nazýva Čarovným princom. Tvrdí mu, že } \\
\text { za svoju zmluvu s diablom zaplatí. }\end{array}$ \\
\hline $\begin{array}{l}\text { Príčinou smrti Jamesa Vana je zastrelenie po- } \\
\text { l'ovníckou puškou. }\end{array}$ & $\begin{array}{l}\text { Príčinou smrti Jamesa Vana je drožka, ktorá } \\
\text { ho zrazí. }\end{array}$ \\
\hline $\begin{array}{l}\text { Dej sa končí nájdením mŕtveho a zostarnutého } \\
\text { Dorianovho tela. }\end{array}$ & $\begin{array}{l}\text { Mrs. Leaf prichádza v smútočnom odeve do } \\
\text { podkrovnej izby, ktorá je prázdna a čistá. Roz- } \\
\text { tvára závesy a dovnútra vpúšta slnečné svetlo. } \\
\text { Tým sa dej končí. }\end{array}$ \\
\hline
\end{tabular}

Komparáciou literárnej predlohy a libreta opery Dorian Gray sme zistili, že medzi nimi nie sú značné odchýlky, ktoré by výrazne menili podstatu deja. Tam, kde Oscar Wilde využil opis - ako napríklad zoznámenie sa Sibyl Vane a Doriana Graya -, libretistka napísala dueto, pretože práve to je možnostou zaujímavého dramatického rozvíjania deja. Situácie, ktoré pre ňu nespĺňali požiadavky dramatického rozvíjania deja, do libreta nevložila. 


\section{Hudobná reč opery}

Slovenské národné divadlo uvádza pôvodné slovenské opery len sporadicky. Táto opera preto vzbudila o to väčšie očakávanie. Na dvoch premiérových predstaveniach diela Dorian Gray sa zúčastnilo pätnást' recenzentov z renomovaných domácich i zahraničných printových a elektronických médií. ${ }^{0}$ Dielo vzbudilo záujem u kritikov a publicistov, ktorí spolupracujú s The New York Times, Opera New London, Opernwelt, s agentúrou SITA a mnohými d’alšími známymi médiami. ${ }^{51}$ Operu po premiére zhodnotil aj známy recenzent Friedrich Reininghaus. Podla neho „... Bratislavu po dlhšom čase obohatilo dielo mladej umelkyne, ktorá je rezidenčnou skladatel'kou vel'kého nemeckého vydavatel'stva."52

Hoci sa prepisom do libreta určitá filozofická rovina pôvodného románu vytratila, značnú čast' saturuje hudba. Hudobná zložka je postavená na kontrastoch jednoduchého a zložitého, krásneho a dekadentného, tonálneho a atonálneho. Hudobný materiál opery Dorian Gray je postavený monotematicky, základnou charakteristikou je jeho variabilita - v partitúre možno nájst' viacero príbuzných hudobných tém, $\mathrm{s}$ ktorými autorka pracuje $v$ rôznych hudobných variáciách. Hudobný vývoj opery Dorian Gray smeruje od konvenčného úvodného dejstva k harmonicko-rytmicky odvážnejšiemu rázu a kontrastnému charakteru. $V$ rámci prvého dejstva autorka využíva prehl'adnú orchestrálnu sadzbu - dlhé rytmické hodnoty konsonantných súzvukov, ktoré u poslucháča môžu svojou jednoduchostou evokovat’ atmosféru "estétstva“ - prílišného zamerania sa na vonkajšiu krásu, z ktorého sa zrodil portrét Doriana. V druhom a tret’om dejstve sa hudba stáva "aktívnejšou“, skladatel'ka v nich viac pracuje s disonanciou. Zvukovo vyostrené disonantné intervaly, tmavá inštrumentácia orchestra, temný až agresívny spevácky prejav hlavného hrdinu, prebiehajúci v rozmanitých dynamických rovinách a prednesových výrazoch, sú hlavnými charakteristickými znakmi pre finále opery. Výraznou súčastou kompozičného jazyka, objavujúcou sa v priebehu celej opery, sú dlhé, hutné akordické súzvuky vyššej terciovej stavby. George Loomis v The New York Times uviedol, že „... Čekovskej štýlje zrozumiteliný, jemne disonantný, s lyricky profilovanými hlasovými líniami zvýrazňujúcimi nepokojnú povahu románového diela Oscara Wilda." ${ }^{53}$

Vzhladom na rozsah práce uvedieme najzaujímavejšie hudobné momenty opery Dorian Gray. Opera je z hladiska nástrojového obsadenia komorne ladeným dielom, inštrumentácia je organická a vyvážená. Inštrumentácia na niektorých miestach necháva vyzniet' spievané slovo. Inokedy je zas dramaticky vypätá - je zvukovo a farebne bohatá, poslucháča vtahuje do atmosféry jednotlivých dramatických situácií. Opera je vokálne postavená na áriách, duetách, tercetách a ansámblových číslach. Nemožno povedat', že ide o číslované árie podla tradície starej opery, ale o prekomponované úseky s bohatou vokálnou variabilitou. Tónový rozsah vokálnych partov jednotlivých postáv sa pohybuje v prirodzenom rozmedzí daných hlasových odborov. Lubica Čekovská v rozhovore pre časopis Hudobný život uviedla:

„.... vel'mi som sa snažila, aby sa opera dala dobre interpretovat.' Vokálne party som si sama prespievala, tiež som ich konzultovala s manželom Svetom. On mi poskytol cenné rady ohladne prechodných tónov a d'alších špecifík jednotlivých hlasových odborov. ${ }^{154}$ 
Na poslucháča môže však stereotypne pôsobit’ neustále sa opakujúce ukončenie vokálnych fráz vysokým tónom. Zaujímavost̉ou je, že jednotlivé vokálne party hrdinov sú často komponované bez orchestrálneho sprievodu.

Opera má z hladiska tektonickej výstavby prekomponovanú štruktúru. V opere možno nájst’ aj inštrumentálne intermezzá a dve samostatné hudobné čísla, konkrétne Cirkus atonal a Tanec tureckého mládenca. Tieto hudobné čísla sa však svojím hudobným jazykom odlišujú od jazyka opery, autorka ich využíva ako signál vstupu do lacného „low-budget" londýnskeho divadla, v ktorom účinkuje Sibyl Vane. Spočiatku prehladná harmónia a melodika postupne graduje ku klastrom, glissandám a neprirodzeným polohám jednotlivých hudobných nástrojov.

Anglický dirigent Christopher Ward považuje hudobný jazyk Ĺubice Čekovskej za pestrý, vel'mi náročný, dramatický, značne štylizovaný. ${ }^{55}$ Pavol Smolík uvádza, že „... autorka bohato využíva symbolické vyjadrenia a dejové skratky, ktoré čoraz viac rezonujú v postupne sa odhalujúcom posolstve diela - takže diváka udržiavajú v stálej pozornosti." ${ }^{\prime 56} \mathrm{~V}$ partitúre v tomto zmysle možno nájst' viacero zaujímavých, často sa opakujúcich momentov. Takým momentom je napríklad ostinato, ktoré z hladiska symboliky skladatel'ka vysvetl'uje nasledovne:

„Ostinato je metaforou zloby, ktorá sa nám - presne a vytrvalo dávkovaná - zadiera pod kožu, až ju prijmeme za pravdu. Navyše v diele funguje čosi ako metronóm odpočítavajúci čas. ${ }^{157}$

Rovnako často možno nájst’ aj interval $d-g$, čo možno chápat’ ako kryptogram mena titulného hrdinu. ${ }^{58}$ Slovenský kritik Robert Bayer v časopise Hudobný život vo svojom článku Ked'sa milujú muži, ženy sú bezmocné tvrdí, že

„... Čekovskej kompozícia je spolu s konzervatívne prerozprávaným libretom hut-

ným, kompaktným a remeselne vynikajúco zvládnutým príspevkom do súčasnej hudobno-dramatickej spisby."

\section{Charakterizácia postáv opery Dorian Gray}

\section{Dorian Gray}

Charakter Doriana Graya ako dramatickej opernej postavy sa v podstate nelíši od jeho románového predobrazu. Preto sa teraz budeme venovat' hlavne hudobným charakteristikám tohto hrdinu.

Pokial' ide o hlasové zaradenie Doriana Graya, autorka zvolila tenor. Táto postava je z hladiska jej vokálneho partu najnáročnejšou postavou opery. Takmer po celý čas opery (cca 2,5 hodiny) neopustí scénu. Jeho vokálny part je napísaný v rozsahu od $e^{1}$ po his ${ }^{2}$. Náročnost' tohto partu potvrdzuje aj to, že sa zväčša pohybuje na tónoch od $e^{2}$ po his². Interpret si tak len t’ažko oddýchne v nižších polohách. Vokálny part obsahuje pestrú škálu prednesových charakteristík (dolce, delianto, apenato, mestamente, tremendo, furioso, expressivo a pod.). Ideálnym predstavitel'om Doriana Graya je lyricko-dramatický tenor. ${ }^{59}$

Prvý výstup Doriana Graya sa odohráva hned' v prvom dejstve a prvej scéne. Hudobne je jeho príchod spracovaný nasledovne: ked' Dorian prichádza, zaznieva krátka hudobná čast', ktorá poslucháčovi môže pripomínat’ fanfáru (drevené a plechové dychové nástoje). Výrazný prvkom je tu dynamika a rytmus. Túto čast’ možno 
chápat’ nasledovne: fanfára je krátka hudobná skladba, ktorá sa najčastejšie hrá pri dôležitých slávnostiach. Fanfáry zaznievajú tiež pri uvítaní vzácnej návštevy. V tomto prípade je vzácnou návštevou Dorian. Skladatel'ka tak atmosféru Dorianovho príchodu umocnila využitím takejto „fanfáry“, ktorá poslucháčovi už od začiatku napovedá, že Dorian je osobnost', ktorá v priebehu deja nadobudne vel'ký vplyv na l'udí, ktorých má okolo seba.

Notový príklad 1: Hudba pripomínajúca fanfáru ${ }^{60}$
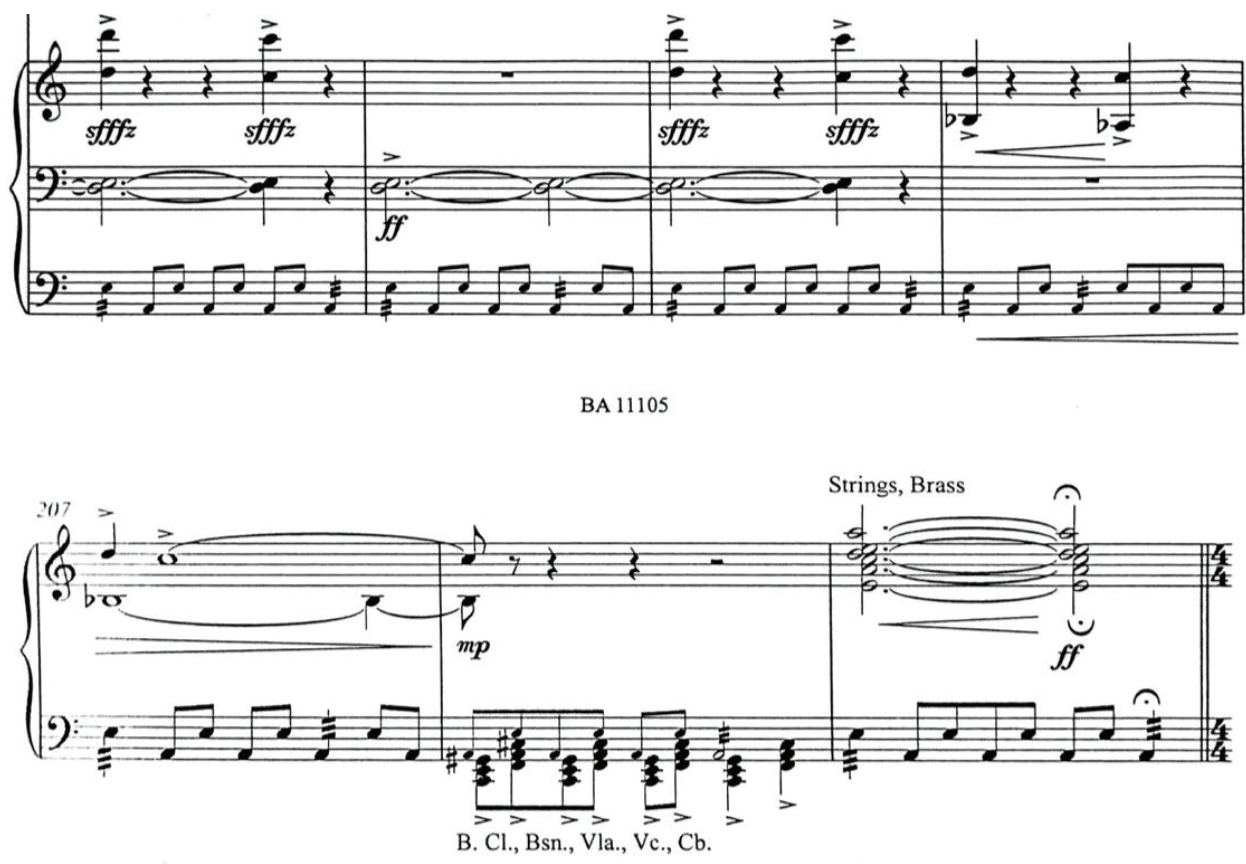

Dorian prichádza ako mladý muž plný energie a dobrej nálady. Vchádza do ateliéru, zamieri priamo ku klavíru, zatial' čo obraz ignoruje. Oznamuje Basilovi, že túži hrat’ na klavíri a nik ho nezastaví. Dorianove úvodné slová znejú: „I am going to play the piano. I am longing to play the piano today. Basil, you can't stop me - I am playing the piano today! "61 [Idem si zahrat' na klavíri. Dnes túžim hrat’ na klavíri. Nezastavíš ma, Basil dnes budem hrat’ na klavíri!]. ${ }^{62}$ Dorianov nástup je energický. Vokálny part je na tomto mieste spevný, jeho zasnená melódia v spojitosti so sprievodom, v ktorom dominuje čistý zvuk čelesty a vibrafónu, má až rozprávkový charakter.

Následne prichádza kontrast. Basil zoznamuje Doriana s lordom Henrym. Je zrejmé, že Dorian je ohromený stretnutím s Henrym, okamžite to medzi nimi zaiskrí. Zatial' čo Dorian pózuje maliarovi Basilovi, lord Henry filozofuje o živote. Dorian ho s údivom a obdivom pozorne počúva.

Hudba začne získavat' iný charakter hned' po tom, ako sa Dorian zoznámi s lordom Henrym - napríklad po prvýkrát zaznieva klaster, ktorý do hudobného toku prináša znepokojenie. Od tohto momentu až do chvíle, ked' Dorian vysloví svoju túžbu po večnej mladosti a kráse, za ktorú dá dušu, je hudba niekedy až príliš jednoduchá - vo- 
kálne party sú dokonca bez orchestrálneho sprievodu, aby lepšie vynikla naliehavost’ ich obsahu.

Notový príklad 2: Dorianove vokálne party bez orchestrálneho sprievodu ${ }^{63}$
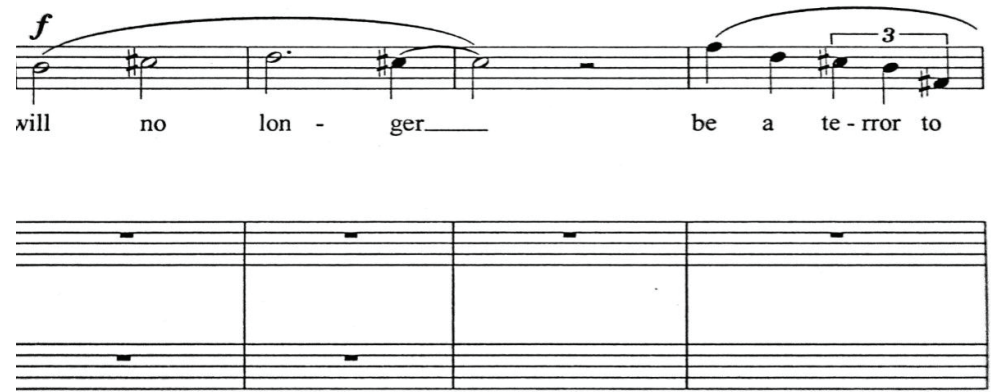

Inokedy je hudba zase temná - dramaticky vypätá, disonantná a melancholická. To možno chápat’ ako úsilie autorky vytvorit’ tajomnú atmosféru, rovnako, ako je tajomný a nečitatel'ný Dorian. V momente, ked' Dorian ponúkne svoju dušu za večnú mladost' a krásu, ozvú sa Hlasy obrazu, zatial'v pôvodnom, „,čistom“ znení.

Hudba prestáva byt' "tajomná“ v momente, ked’ sa Dorian dozvedá o samovražde svojej snúbenice Sibyl Vane. Od tohto momentu sa vokálny part Doriana Graya stáva melancholickým a sprevádza ho disonantná harmónia - v hlbokej polohe si možno všimnút ostinátne opakovanie tónu, ktoré u poslucháča môže evokovat’ už spomínaný „metronóm času”.

Notový príklad 3: Ostinátne opakovanie tónu ${ }^{64}$

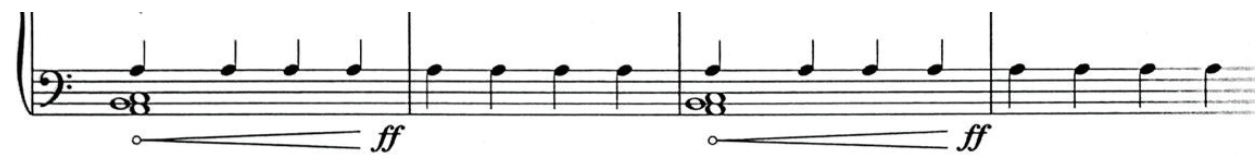

Dorianov vokálny part sa opakovane končí na vysokom tóne, čo u poslucháča môže evokovat’ výkriky, spôsobené zúfalstvom a beznádejou.

Najviac dramaticky vypätý výstup Dorian Graya sa odohráva v scéne číslo 15, po smrti Alana Campbella. Dorian si začína uvedomovat’ svoje hriechy. Zdá sa, že ich úprimne l'utuje.

"In what wild hour of madness

have I killed my friend?

Basil - And Sibyl Vane.

Alan Campbell, and now James Vane.
[V akom to pomätení zmyslov zabil som svojho priatela?

Basil - a Sibyl Vane.

Alan Campbell, a teraz James Vane. 
This mirror of my soul

Is not just, not true -

The only piece of evidence left.

Why have I kept it?

I must destroy it,

This picture is evidence of my sins.

Why have I kept it?

I must destroy it,

It keeps me awake at night.

It is my conscience.

I'll kill the past and when that is dead

I will be free

I'll kill this monstrous soul,

and then I will be at peace. ${ }^{65}$
To zrkadlo mojej duše nie je presné, nie je pravdou jediný dôkaz, čo ostal. Prečo som si ho nechal? Musím ho zničit', ten obraz je dôkaz mojich hriechov.

Prečo som si ho nechal?

Musím ho zničit',

v noci mi nedá spat'.

Je mojím svedomím.

Zabijem minulost' a ked' tá zomrie budem slobodný.

Zabijem túto obludnú dušu.

Potom nájdem pokoj.] ${ }^{66}$

Dorian túži začat' nový život. Po prvýkrát nahlas vyslovuje, že obraz je jeho svedomím. Odráža v sebe každý jeho hriech, všetko zlé, čo v živote vykonal. PIný odhodlania sa rozhodne konat'. Je si istý tým, čo musí urobit' - zničit’ svoj zdevastovaný portrét. Dúfa, že tým sa jeho duša očistí, dokonca z jeho slov vyplýva, že je ochotný podstúpit’ aj verejné poníženie a hanbu. Čekovská moment uvedomenia si hriechov, túžbu po novom živote a následnú smrt' Doriana spracovala napínavo. Od chvíle, ked' Dorian vysloví, že chce začat' nový život, až do momentu, ked' povie o obraze: „Why have I kept it? I must destroy it" ${ }^{\prime \prime 67}$ [Prečo som si ho nechal? Musím ho zničit'] ${ }^{68}$ sprevádza Doriana len zvuk vibrafónu a harfy (na niektorých miestach trioly harfy, inde opakujúci sa interval $\left.e-d i s^{2}\right)$. Tieto nástroje sú v opere charakteristické najmä pre postavu Sibyl. Možno to teda chápat’ ako autorkin zámer zdôraznit', že ho výčitky zo smrti Sibyl prenasledujú a trápia.

Notový príklad 4: Sprievod harfy ${ }^{69}$

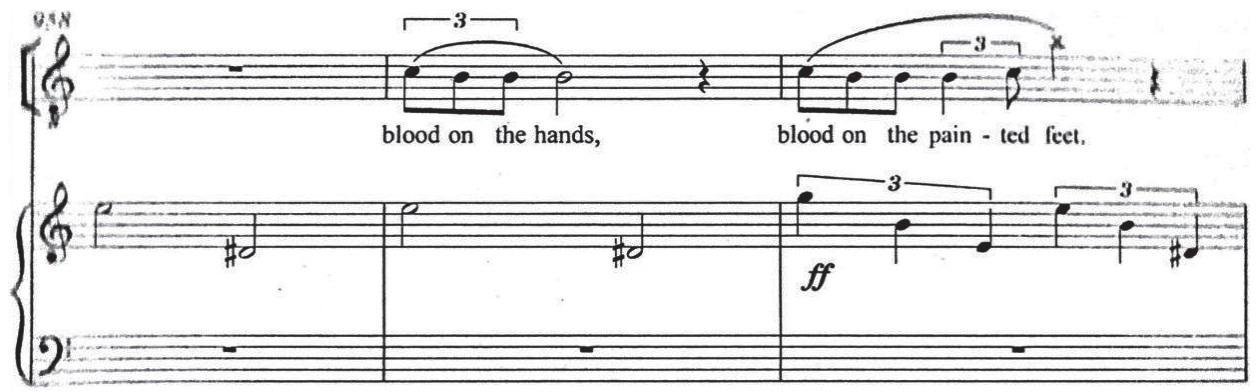

Na miestach, kde nezaznieva harfa a vibrafón, znejú glissandá trombónov. V momentoch, ked' Dorian spieva dlhý tón, sa v celom takte objavujú glissandá violončiel. 
Notový príklad 5: Glissandá trombónov a violončiel ${ }^{70}$

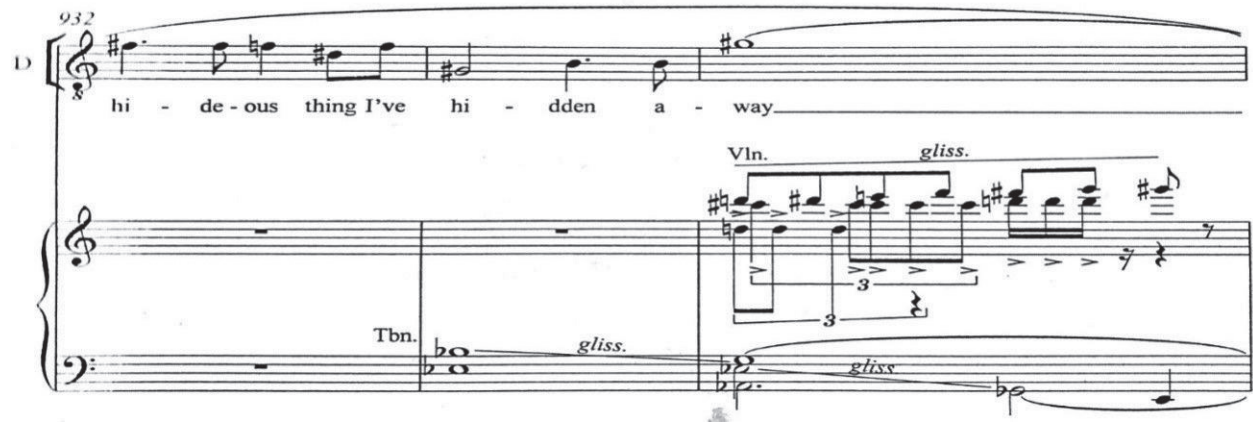

Práve glissandá trombónu a violončiel môžu na poslucháča pôsobit' až démonicky. Na iných miestach sú naopak Dorianove vokálne party bez orchestrálneho sprievodu. To možno chápat’ ako autorkin zámer zdôraznit', že Dorian je v tomto momente skutočne sám a prežíva obrovský strach. Inštrumentácia začína byt’ zvukovo plnšia od vyslovenia Dorianových slov "Why have I kept it? I must destroy $i t^{u 171}$ [Prečo som si ho nechal? Musím ho zničit']. ${ }^{72}$ Vtedy už autorka začína využívat' hutné, disonantné akordy vyššej terciovej stavby. Dorianove posledné slová sú „„... and then I will be at peace ${ }^{173}\left[\right.$... potom nájdem svoj pokoj]. ${ }^{74}$ Dorian sa obzerá po izbe a zbadá nôž, ktorým zabil Basila. Bodne do obrazu. Je to však práve Dorian, kto skríkne a v agónii zomiera.

V záverečnom symfonickom epilógu využila autorka hudby akordy vyššej terciovej stavby v tutti obsadení orchestra. Napriek tomu sa pohybuje už len v piano (tiež $p p$, $p p p, p p p p)$. To môže mat’ svoju symboliku: Čekovská svojim divákom prostredníctvom takejto chvíle, ked' hudba doznieva v piane, necháva otvorený priestor na premýšlanie, či si hlavný hrdina zaslúži „rozhrešenie“.

Notový príklad 6: Záverečné takty symfonického epilógu75
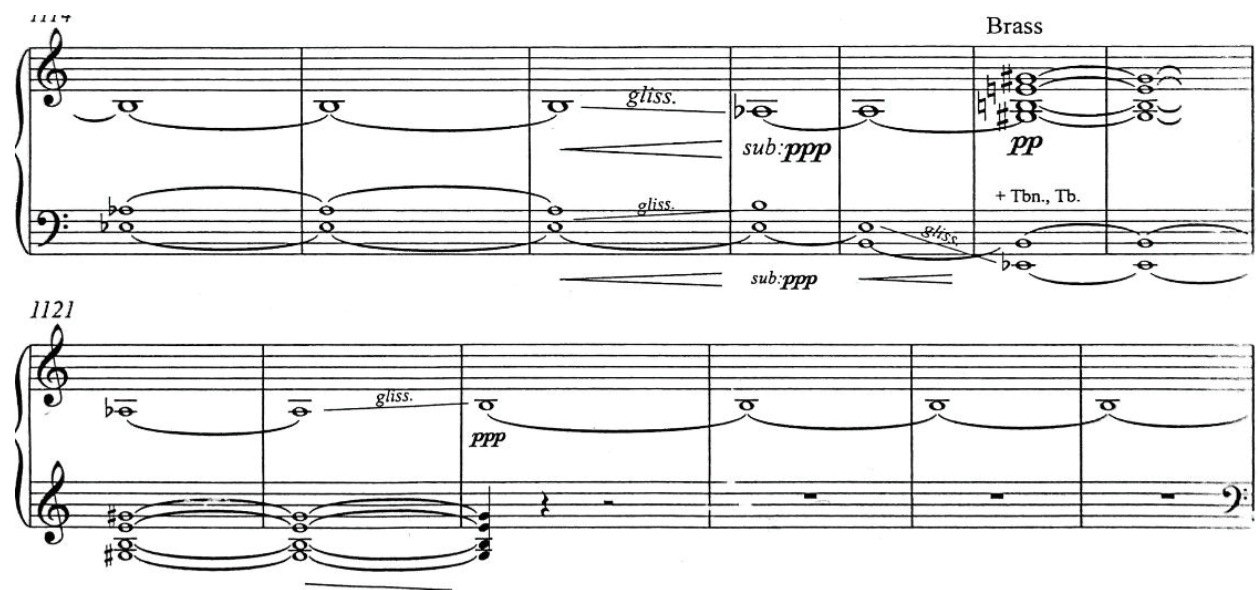


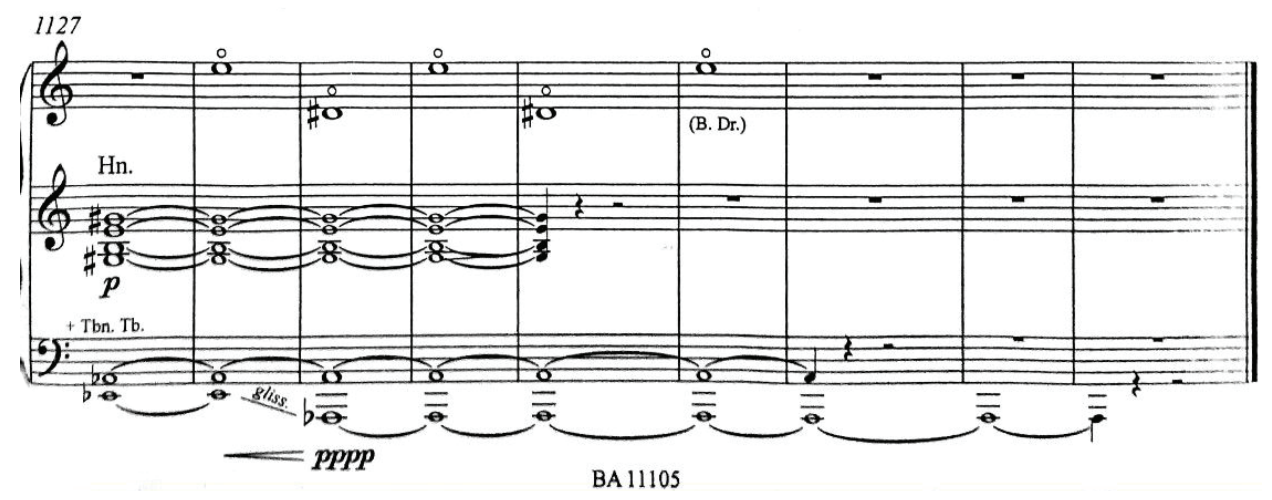

Hlasy obrazu - leitmotív Doriana Graya

To, čo Doriana Graya charakterizuje najviac, je odraz jeho svedomia, tzv. leitmotív a tažisková téma celej opery - Hlasy obrazu - ktorou Lubica Čekovská ,... dopomohla k modernému tvaru inscenácie úplne geniálnym trikom, a síce hudobným stvárnením obrazu Doriana, ktorý vytvorila použitím chlapčenských sopránových hlasov." ${ }^{176}$ Téma zaznieva v momentoch konfrontácie hlavného hrdinu so svojím portrétom. $S$ postupnou deštrukciou hlavného hrdinu nadobúda pôvodne čistá línia démonické podoby hriechmi rozleptanej Dorianovej duše.

Téma nezaznieva počas opery v interpretácii orchestra, ale púšta sa zo záznamu. Jej pôvodný tvar naspieval a nahral Bratislavský chlapčenský zbor. Variácie témy boli vytvorené elektroakusticky v štúdiu v Pariži. Tému do jednotlivých hudobných variácií upravil Robert Rudolf, osobnost' slovenskej elektroakustickej hudby a radioartu. Robert Rudolf spolu s Ĺubicou Čekovskou viedli pred samotnou prácou na jednotlivých hudobných variáciách témy Hlasu obrazu podrobné rozhovory. Počas nich sa postupne kryštalizovala konkrétna predstava Čekovskej, ktorou boli „.... viaceré zvukové predely s rovnakou tematikou a postupným odklonom od ich pôvodného tvaru".77

"Od samého začiatku som chcela, aby bolo obraz hlavne počut, preto mi Bratislavský chlapčenský zbor nahral akýsi hlas obrazu, ktorý som neskôr dala zmodulovat'v elektroakustickom štúdiu v Pariži, ${ }^{178}$ uviedla Čekovská. Podla slov Roberta Rudolfa nebola autorkina predstava spočiatku celkom presne definovaná. Skladatel'ka však pomerne rýchlo svoju predstavu spresnila a predložila vo finálnej notovej podobe spolu so zvukovými nahrávkami sólistu a chlapčenského zboru.

Počas nahrávania chlapčenského zboru došlo k viacerým komplikáciám. Sólista počas nahrávania začal mutovat. Preto museli autori pristúpit k náhradným riešeniam, ako bol pokus o výmenu sólistu a zároveň pokus o zmenu spôsobu nahrávania. Rudolf uvádza, že „,... oba zvukové súbory sú od seba nezávislé a ich dlžka je upravovaná, takže nezodpovedajú úplne presne pôvodnému notovému zápisu“. Z toho vyplýva, že sólista a zbor neboli zaznamenávaní naraz (simultánne). Pri porovnaní notového zápisu témy a jej výsledného znenia zistíme rozdiely v pomere dížok tónov, čiže v rytme.

Ked' sa nahrávky dostali do rúk Roberta Rudolfa, v snahe zabezpečit ich prijatel'nú hudobnú a technickú kvalitu bolo podl'a jeho slov potrebné vykonat' ešte 
mnoho úprav. Rudolf uviedol, že bolo potrebné korigovat’ intonáciu niektorých miest v sólovom parte, ako aj v zborovom sprievode. Po predložení výsledkov padol skladatel'kin výber na konkrétne upravené sólo chlapčenského sopránu a na sprievodný zbor ako na základný zvukový materiál, od ktorého sa odvíjali hudobné variácie témy.

V literárnej predlohe sa s každým Dorianovým hriechom objaví na obraze „škvrna“. Obraz tak postupne začína "hnit" a stáva sa čoraz šerednejším. Hudobná téma Hlasy obrazu symbolizuje metaforu obrazu. Na javisku sa každý jeden Dorianov hriech prejaví na znení témy. S každým hriechom na seba Hlasy obrazu nabalujú komplikovanejšiu podobu, až vrcholia v démonickom znení.

Pôvodnú tému tvorí 15-taktová melódia sólistu chlapčenského zboru, ktorú doplña harmonický sprievod ostatných hlasov. Hlavnú melódiu spieva soprán zapísaný vo vrchnej notovej osnove, harmonické hlasy v spodnej osnove sú prezentované altom, pod ktorým zaznieva čistá kvarta $v$ hlase spodného altu. $V$ poslednom hudobnom úseku témy zaznieva štvorhlas. Formovo možno tému rozčlenit' na tri hudobné úseky: prvý hudobný úsek predstavuje prvých šest' taktov témy, druhý hudobný úsek prezentujú d’alšie štyri takty a tretí hudobný úsek predstavuje posledných pät taktov. Prvých šest' taktov témy je predpísaných spievat' v piano. Hlavná melódia sa pohybuje na tónoch cis, dis a eis. Na tomto úseku je zapísaná ligatúra, naznačujúca melodický oblúk cez prvých pät taktov. Šiesty takt už len doznieva v harmónii. $V$ dalších štyroch taktoch sa melódia posúva o terciu vyššie a dynamika graduje od mezzoforte do forte. Tretí hudobný úsek možno nazvat kódou témy a to $z$ dôvodu, že $v$ ňom téma doznieva. Hlavná téma hrdinu opery smeruje k centrálnemu tónu cis. $V$ kóde je posledným tónom melódie znejúca sekunda es k príme cis. Tým vzniká nasledovný akord: v spodnom alte gis, alt cis, nižší soprán cis a melodický sopránový hlas s nimi disonuje sekundou es (dis). Disonancia sa objavuje tiež v tret’om riadku v druhom takte ako disonantný súzvuk s g-d-es-c a sopránovým es.

Notový príklad 7: Hlasy obrazu ${ }^{79}$

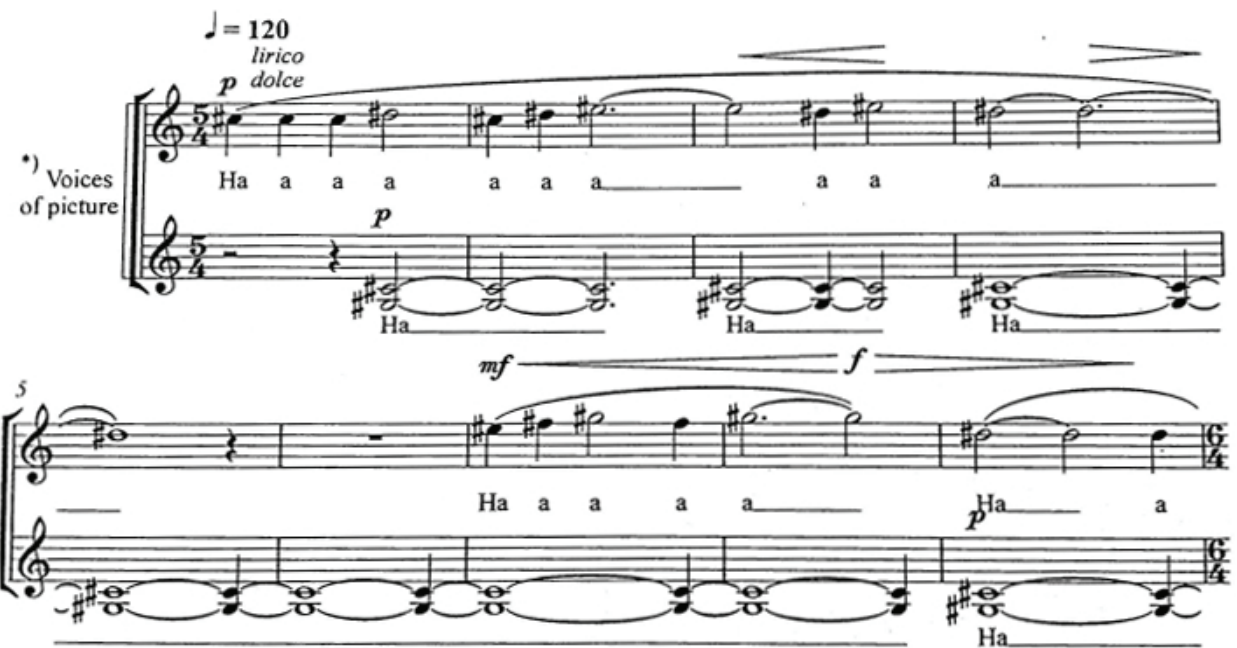




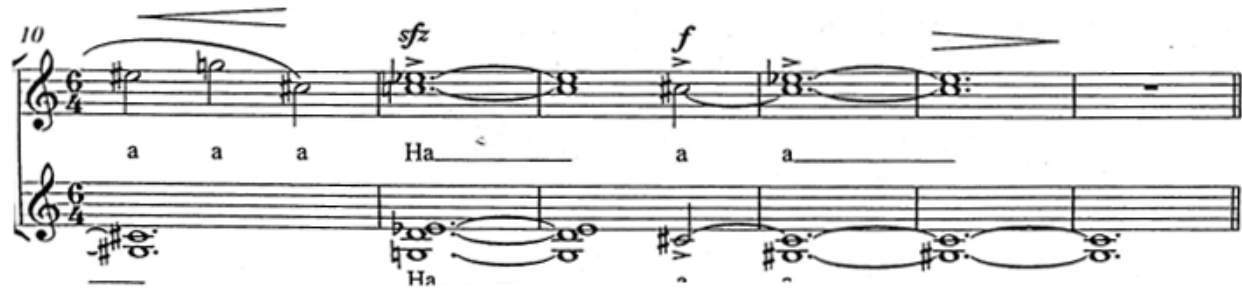

Vývoj témy Hlasy obrazu je podporený dynamikou. Spevná, čistá a jasná melódia zaznieva v piano, s konsonantným sprievodom spodných hlasov v prvých desiatich taktoch. Pod spodnou oktávou v alte zaznieva čistá kvarta - konsonantný, lubozvučný interval, rovnako čistý a nevinný, ako bol Dorian na začiatku - mladý aristokrat, chlapec s čistou a nevinnou dušou. Dynamické označenie piano môže na tomto mieste predstavovat' jeho neskúsenost' a počiatočnú nesmelost'. Následne prichádza ostro disonatný súzvuk v jedenástom takte, s dynamickým označením sforzato (akcent, vel'ký prízvuk), čo môže znamenat’ ostrú charakterovú zmenu, ktorou Dorian prechádza. Rovnako, ako ked' akord zrazu nadobudne z lubozvučného znenia ostrú disonanciu, aj Dorian prechádza charakterovou zmenou vel'mi rýchlo a ostro. A to len preto, že spoznal lorda Henryho, ktorý v krátkom čase zmenil celé Dorianovo myslenie. Dorian začal chodit’ na večierky, ubližovat' ludom, byt' k nim zlý, dokonca začal vraždit'. Dynamické označenie sforzato má tak svoje opodstatnenie - z čistej duše sa za krátku chvílu stalo monštrum. V kóde témy sa síce najprv prinavráti konsonantnost', ale hlavná melódia sa končí disonantne. V takomto „rozladení“ možno hladat’ symboliku: Dorian síce očistil obraz tým, že si svoje hriechy uvedomil a chcel ich napravit’ zničením obrazu - preto v poslednom úseku nastupuje počiatočná konsonantnost'. Dorian však umiera škaredý, starý a odpudivý.

Prvá hudobná variácia zaznieva v prvom dejstve v scéne číslo pät', ked' Sibyl v dôsledku neštastnej lásky k Dorianovi vypije jed a zomiera. Na Dorianovom obraze - v opernom prípade na téme Hlasy obrazu - sa tak objavuje prvá „škvrna“. V prvej variácii pracoval Robert Rudolf výhradne so sólovým hlasom, ktorý prechádzal efektom „delay (PitchAcc), rozdielnym pre každý stereo kanál a pri nezmenenej výške spievaného tónu“" ${ }^{80}$ Znamená to, že hlavná melódia je prerušovaná imitáciami tónov, ktoré nastupujú s rozličným oneskorením. Melódia „blúdi“ v kontrapunkte pôvodného melodického hlasu a jeho „ozvien“. V spleti hlasov je rola zboru ako orientačného prvku o niečo významnejšia než v pôvodnej téme. ${ }^{81}$ Ciel'om Roberta Rudolfa bolo vytvorit’ hlasy mútiace čistotu myšlienok a duše Doriana Graya ako zvodný hlas „erínyí", 82 ktoré však zatial' nemajú príliš vel'ký vplyv na hlavnú postavu.

Druhá hudobná variácia Hlasov obrazu nastupuje v prvom dejstve v scéne číslo šest'. Dorian sa tu dozvedá o samovražde svojej bývalej snúbenice Sibyl Vane. V tejto variácii sa k predchádzajúcim úpravám pridáva „... dynamický (pravdepodobne ručne ovládaný) Shift - GRM Tools“.83 V druhej variácii Robert Rudolf opät’ pracoval „,... výhradne so sólovým hlasom, tak, aby dosiahol mikroladenie zároveň s filtráciou zvuku. ${ }^{\prime 84}$ Hodnoty efektu delay sa menili len nepatrne. Toto prvé „rozladenie“ naznačuje pochybnosti, s ktorými sa Dorian Gray potýka ${ }^{85}$ - či je skutočne zodpovedný za smrt' Sibyl Vane. 
Ďalšia „škvrna“ na téme Hlasy obrazu sa objavuje v druhom dejstve v scéne číslo osem. Dorian Gray spolu s Henrym Wottonom a Alanom Campbellom vchádzajú do ópiového domu. Odohráva sa v ňom typický bohémsky život plný hazardu, alkoholu a sexu. Dorian tu ponúka dvesto libier ako výkupné za štyroch mladých mužov, ktorých chce získat' pre svoje vlastné potešenie. Robert Rudolf píše, že v tretej variácii ,... popri už spomenutých efektoch, potlačených viac do úzadia, ale stále prítomných, vstupuje na scénu paralelný transponovaný hlas, ktorý zdanlivo sleduje melodickú líniu témy. Svojím temnejším a zároveň nevtieravo neurčitým, takmer sínusovým timbrom, vytvára akýsi tieň. ${ }^{186} \mathrm{~V}$ audiozázname opery sú v druhej fráze identifikovatel'né tóny, ktoré síce zaznievajú súčasne s tónmi sopránovej melódie, melodicky však s nimi nesúvisia a z hladiska farebnosti sú poslucháčovi „cudzie“. Pripomínajú ,... neutrálny, elektronicky vygenerovaný zvuk, timbrovo zbavený alikvotných tónov ludského hlasu - zvukového atribútu ludskosti". ${ }^{77}$ Po technickej stránke ide o interakciu viacerých efektov v presnom zoradení Doubler a Morphoder - Waves, Harmony Engine - Antares. ${ }^{88}$

V druhom dejstve v scéne číslo devät prichádza obrovský zlom. Dorian v afekte zabije svojho priatel'a, maliara Basila. V rámci tejto scény zaznievajú až dve hudobné variácie (číslo štyri a číslo pät) Hlasov obrazu v pomerne krátkom čase za sebou. Počas štvrtej hudobnej variácie Rudolf potvrdil prítomnost' "tieňa“ z predchádzajúcej variácie témy a spolu s ním dal do popredia aj,.... mikrotonálnu transpozíciu [zrejme paralelný hlas transponovaný voči hlavnému hlasu v maximálne sekundovom intervale] a delay [aplikovaný na hlavný hlas] vytvárajúci už spomínaný hlas či skôr zbor erínyï."${ }^{\prime 9}$ Medzi takmer - ale nie úplne - identickými tónmi hlavného a paralelného hlasu vznikajú silné rázy. Kým v predchádzajúcich variáciách boli zvukovo rušivé prvky menej výrazné, deformáciu zvuku vo štvrtej variácii už nie je možné ignorovat. ${ }^{90}$

Viacnásobná transpozícia sólového hlasu v paralelných hlasoch sa v piatej variácii potvrdzuje spolu s tŕnistou cestou Doriana Graya. Hlbšie transponovaný „tieň“ prestáva [zrejme dynamicky] kolísat'. Pevnejšie sa spája s líniou pôvodnej melódie, čím ju do istej miery nahrádza. ${ }^{91}$ To, že tento "tieň“ pohltí pôvodne jasnú a čistú melódiu, má svoju symboliku: vplyv Henryho Wottona pohltil Doriana až do takej miery, že sa z neho stalo monštrum, schopné i vraždiț. Z čistej a nepoškvrnenej duše sa stáva duša čoraz viac poznačená hriechmi - práve tú možno chápat’ ako spomínaný zvukový „tieň“. Ako uvádza Rudolf, sprievodný zbor ustupuje do úzadia, i ked' je v úvode témy ešte „oporou“ melodickej línie. V d’alšom priebehu podlieha už aj zbor "statickému preladeniu“.92 Vysvetl'ujeme si to ako jeho transpozíciu v celej dĺžke trvania tejto variácie. V tomto momente už Dorian nie je tým, kým kedysi býval.

Šiesta hudobná variácia sa objavuje na konci druhého dejstva v scéne číslo desat'. Dorian sa vyhráža Alanovi Campbellovi, že ak sa nezbaví Basilovho mŕtveho tela, odošle médiám list o Alanovej škandalóznej minulosti. $V$ rámci tejto variácie dochádza „... k podstatnému zlomu v oblasti vývinu postupných zmien". ${ }^{93}$ Pôvodný sólový hlas

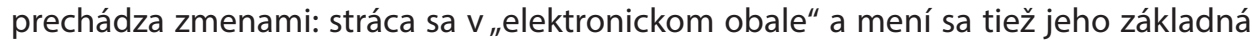
farba. Farebný posun má podla Rudolfovho zámeru sledovat' vývoj osobnosti hlavnej postavy. Téma sa stáva menej určitou. „Rozladenie“ spolu s efektom delay postupne prechádza do prvého plánu a zmeny sa stávajú kompaktnejšími. ${ }^{94}$ Efekty „"parazitujúce" 
na slabnúcich tónoch pôvodnej témy sú už takmer plne zvukovo emancipované. ${ }^{95}$ Môžu symbolizovat’ Dorianove hriechy, kvôli ktorým začína jeho duša „hnit"'. Pôvodné zafarbenie chlapčenského sopránu stráca timbrovú čistotu. ${ }^{96}$ To, že Dorian prinútil Alana odstránit’ Basilovo mŕtve telo, je v rámci deja opery Dorianovým posledným hriechom. Asi preto je už pôvodne jasná téma pre poslucháča temer nerozoznatelná.

Siedma hudobná variácia zaznieva v tret’om dejstve, v scéne číslo trinást'. Dorian sa tvárou v tvár stretáva s bratom Sibyl, Jamesom, ktorý ešte pred smrtou svojej sestry prisahal, že ak jej Dorian ublíži, zabije ho. James však kvôli mlado vyzerajúcej tvári Doriana nespozná a nechá ho odíst'. „Bordelmama“ mu však následne prezrádza, že Dorian zapredal dušu diablovi, a preto vyzerá tak mlado. Melodická línia sa slovami Roberta Rudolfa pod nánosom akumulovaných efektov ako je transpozícia, namnoženie hlasov, delay a i. úplne stráca a tieto prvky nahrádzajú pôvodnú tému. Sprievodný zbor úplne absentuje. Na jeho mieste sa objavuje nový prvok v podobe elektronicky vygenerovaného šepotu. ${ }^{97}$ Možno ho chápat’ ako predzvest' neštastia - Dorian je na tomto mieste už skutočne pomätený. Postupne si uvedomuje rozklad svojej duše, odrážajúcej sa na obraze. V úvode variácie počujeme stúpajúce tóny vyvolávajúce napätie. ${ }^{98}$ Sám cíti, že sa blíži niečo hrôzostrašné a má obrovský strach. Šepot je náhradou zborového sprievodu a zároveň farebným doplnením zvuku variácie. Na želanie Čekovskej však Rudolf tento šepot potlačil do úzadia. ${ }^{99}$

V poradí ôsma hudobná variácia zaznieva v tret’om dejstve, v scéne číslo štrnást'. Dorian vo svojom dome organizuje večierok. Je zrejmé, že nechce byt’ sám, pretože so začínajúcou pomätenostou sa ho zmocňuje strach. Farba zvuku sa mení a filtráciou je ochudobnená o charakteristický rozmer l'udského hlasu. Výsledkom je napoly elektronický, napoly ludský zvuk, ktorý spolu s už spomenutým šepotom dotvárajú premenu Doriana Graya. ${ }^{100}$ Dorian má halucinácie - počuje mŕtvy hlas Sibyl Vane. Zvonka sa ozýva krik. Družka zabila Jamesa Vana, ktorý sa chystal Doriana zavraždit'. Dorian si začína uvedomovat', kol'ko ludí kvôli nemu prišlo o život. S tým súvisí masa hlasov, ktorá sa prečistí tak, že jednotlivé melodické línie získavajú na samostatnosti. Sledujú celkom nezávislé smery. ${ }^{101}$ Hrôzostrašné zvuky doliehajúce na scénu - ako naznačuje melódia - „z rôznych smerov", už skôr ako reflexiu vnútra hlavného hrdinu pripomínajú dôsledky jeho činov. KÍzavé glissandá smerom zhora nadol zaznievajú nekoordinovane v ostrých vysokých i temných nízkych polohách. Spomedzi zvukov, chtiac-nechtiac evokujúcich kvílenie, sa v závere variácie vynára jeden, a o niečo neskôr d’alší tiahly tón. ${ }^{102}$ Dorian si je istý tým, čo urobí.

Posledná, deviata hudobná variácia Hlasov obrazu zaznieva na konci tretieho dejstva, v scéne číslo pätnást'. Ešte predtým ako zaznie, Dorian bodne do obrazu. Bodnutím do obrazu zabíja svoju minulost', ale je to práve Dorian, ktorý zomiera. O niečo dlhšia záverečná variácia prináša do procesu postupných zmien nový prvok, ktorým je elektronicky upravená melódia sólového hlasu. Táto úprava znižuje kvalitu sólového hlasu a výsledkom sú akustické „parazity“. Opät” sa objavuje šepot, a následne sa už elektronicky upravená pôvodná melodická línia znovu dostáva do popredia. V tejto fáze „„.. zvádza súboj so svojimi predchádzajúcimi premenami, transpozíciami a inými prvkami procesu." ${ }^{\text {03 }}$ Rušivých akustických prvkov, ktoré sa v priebehu variácií nabalili na pôvodnú tému, „ubúda“: dynamicky sú čoraz viac v úzadí a pôvodná téma so vzrastajúcou dynamikou vystúpi do popredia. ${ }^{104}$ 
V literárnej predlohe smrtou Doriana nadobudne obraz svoju počiatočnú podobu. V opere po Dorianovej smrti naposledy zaznieva pôvodná, "čistá" téma. Dorian bodnutím očistil hriechmi zdeformovaný portrét. V tomto momente už „kúzlo“, vd’aka ktorému ostal Dorian tol'ký čas mladý a krásny, úplne pominie. Práve z toho dôvodu sa hrôzostrašná podobizeň obrazu prenáša na samotný výzor Doriana. Opätovným zaznením pôvodnej melódie sa tak síce obraz vyčistí, ale Dorian umiera ako odpudivý a šeredný starec. Posledný tón melódie témy preruší mohutný klaster orchestra s dynamikou vo forte-fortissimo. Takéto príliš "hlučné" a disonantné ukončenie jeho života môže znamenat', že Dorian pravdepodobne nenájde pokoj ani po smrti.

\section{Sibyl Vane}

Charakterovo je operná Sibyl Vane v podstate totožná s románovou. Je najlyrickejšou postavou opery. Skladatel'ka pre ňu zvolila soprán. Sibyl je svojím počiatočným charakterom - definovaným vyššie - typologicky vhodná pre lyrický soprán, prirad'ujúci sa zväčša mladým, krásnym a nežným ženám. Jej neštastie a tragický osud ju však posúva práve do mladodramatického odboru. To nám môže potvrdit aj spôsob kompozície jej vokálneho partu v jednotlivých scénach, ktorý sa pohybuje v rozsahu od $c^{1}$ po $a^{2}$. Jej spev nie je postavený na velkých intervalových skokoch, práve naopak, je menej pohyblivý. Autorka tu často využíva dlhé rytmické hodnoty, u Sibyl nemožno nájst' melodické behy či koloratúry. $V$ spojitosti s textom si tento vokálny part vyžaduje farebnejší a plnší hlas. Ked'sa pozrieme na definíciu jednotlivých sopránových odborov ${ }^{105}$ zistíme, že práve tieto znaky sú charakteristické pre mladodramatický soprán.

Prvý výstup Sibyl Vane sa odohráva na začiatku druhej scény. Divák sa ocitá v prostredí každodennej prevádzky londýnskeho divadla, plného lesku, žiarivého svetla a scénických ozdôb. Hladisko je plné. Sibyl Vane vstúpi na javisko a obecenstvo búrlivo tlieska. V momente, ked' Sibyl začína spievat', obecenstvo stíchne. Na javisku stojí sama. Je nádherná a jej kostým sa na javisku ligoce.

Sibyl v árii spieva monológ Ofélie zo Shakespearovej hry Hamlet. Ako sme už spomínali v predchádzajúcich kapitolách, vo Wildovej predlohe prichádza Dorian do divadla na predstavenie Shakespearovej hry Rómeo a Júlia, kde po prvýkrát uvidí Sibyl, prednášajúcu monológ Júlie. S návrhom vymenit’ monológ Júlie za monológ Ofélie neprišla samotná libretistka Kate Pullingerová, ale režisér David Pountney. Prečo sa rozhodli tento monológ nahradit? Obe postavy sa zrodili z pera jedného z najvýznamnejších anglických dramatikov Williama Shakeaspeara. Júlia verne a oddane milovala Rómea rovnako ako Ofélia Hamleta. Obe boli mladé, krásne a nežné ženy. Ani jedna z nich sa nevedela vyrovnat' so stratou svojej lásky, a tak sa rozhodli ukončit' svoj život. Tu možno nájst' paralelu s postavou Sibyl - rovnako mladou a krásnou ženou, verne milujúcou Doriana Graya. Podobne ako Júlia a Ofélia sa ani Sibyl nevyrovná so stratou svojho milovaného muža a spácha samovraždu. Ked' Júlia uvidí mŕtveho Rómea, od žialu sa zabije. Ofélia sa pomätie. Otázne zostáva, či Oféliino pomätenie vyvolá neštastná láska k Hamletovi, smrt' jej otca, alebo fakt, že bola ženou manipulovanou mnohými mužmi. Shakespeare necháva svojim čitatelom otvorený priestor, aby si skutočný dôvod domysleli sami. Sibyl Vane rovnako ako Ofélia zošalie, ked' ju opustí milovaný muž. Vyššie spomínaný monológ je monológom Oféliinho šialenstva. Sibyl tento monológ spieva v čase, ked'sa po prvýkrát stretáva s Dorianom. Ked'Ofélia vysloví „he is dead and gone, lady..." a „... with true-love showers" ${ }^{106}$ [už umrel, pani, umrel mi...] a [...ach, slzy, kropte 
hrob], ${ }^{107}$ nie je isté, či myslí smrt' svojho otca, alebo smrt' vzt’ahu s Hamletom. Z úst Sibyl však tieto slová naberajú jednoznačnejší význam - možno ich chápat’ ako predzvest’ smrti vztahu medzi Sibyl a Dorianom a jej následnú samovraždu.

"How should I your true love know

From another one?

By his cockle hat and staff

And his sandal shoon.

He is dead and gone, lady,

He is dead and gone;

At his head a grass-green turf,

At his heels a stone.

White his shroud as the mountains now Larded with sweet flowers

Which bewept to the grave did go

With true-love showers"108
[Ako si svojho milého od iných rozoznám?

Pútnická čiapka, sandále, a na palici dlaň.

Už umrel, pani, umrel mi, viac neprekročí prah, už má len trávu nad hlavou a kameň pri nohách.

Má biely rubáš zo snehu. Ach, dáždiček, len krop tie kvety, mrúce na nehu! Ach, slzy, kropte hrob! ${ }^{109}$

Ária Sibyl je v celej opere jediná, ktorá svojou formou pripomína klasickú formu árie. Pri písaní tejto árie sa autorka rozhodla využit tri violončelá, husle, dve flauty, vibrafón, hoboj, anglický roh a harfu, ktorá je klúčovým nástrojom spojeným so Sibyl. V prvých taktoch árie pri slovách "How should l your true love know From another one?" ${ }^{\text {"110 }}$ [Ako si svojho milého od iných rozoznám?] ${ }^{111}$ sprevádzajú Sibyl len trioly harfy a miestami sa ozve zvuk vibrafónu. Prosté trioly harfy zaznievajú po celý čas. Možno ich azda chápat’ ako symbol prostej a naivnej lásky Sibyl k Dorianovi.

Notový príklad 8: Trioly harfy v árii Sibyl ${ }^{112}$

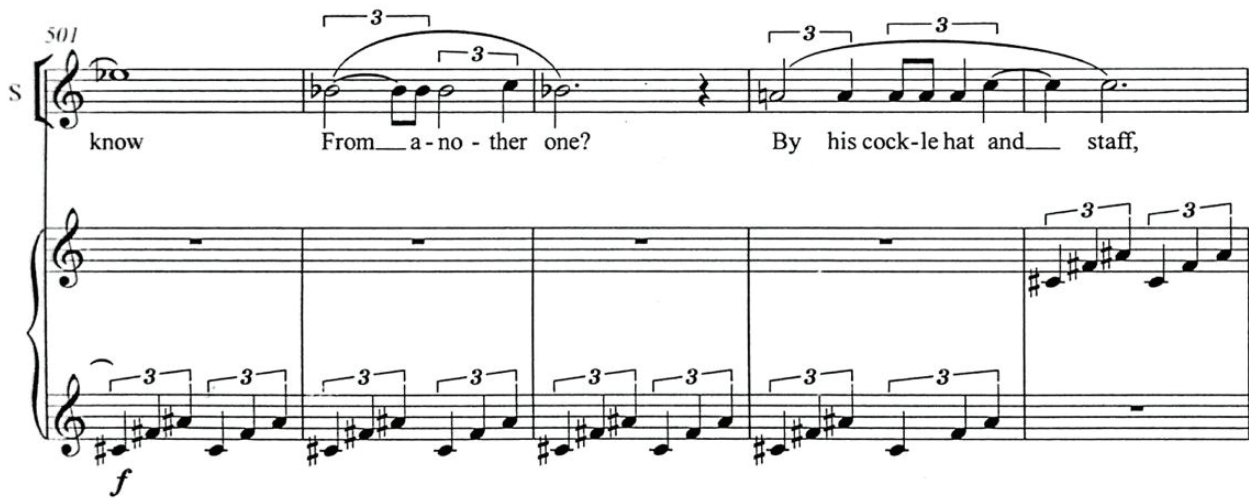

Ked' Sibyl vysloví „with true-love showers..." ${ }^{113}$ [už umrel, pani, umrel mi...], ${ }^{114}$ trioly harfy nad’alej plynú, harmónia však nadobudne temnejší charakter: pridajú sa dychové nástroje ako hoboj, flauta, klarinet a anglický roh. Od tohto momentu sa inštrumentácia nemení, harmónia sa však rozširuje o akordy vyššej terciovej stavby. Trioly harfy, symbolizujúce vernú lásku Sibyl k Dorianovi, stále znejú, poslucháč ich 
však len t’ažko rozozná. V čoraz melancholickejšom harmonickom toku sa postupne strácajú, čo možno chápat’ ako zámer autorky poslucháčovi naznačit', že láska medzi Sibyl a Dorianom nebude mat' štastný koniec a „niečo“ ju naruší. Spočiatku lyrická ária tak smeruje k dramaticky vypätému výrazu plnému harmonických a dynamických zmien, s častými zmenami tempa. Vo vokálnom parte tejto árie autorka často využíva akoby melizmatický spev na vokál „a“, ktorý u poslucháča môže vyvolat’ dojem plaču a hysterických vzlykov zúfalej ženy.

Notový príklad 9: „Melizmy“ pripomínajúce plač a vzlyky v árii Sibyl ${ }^{115}$

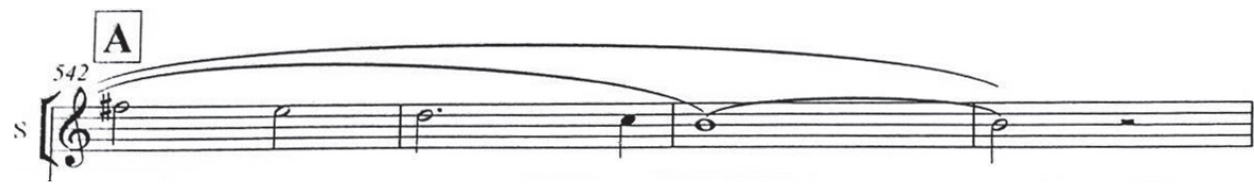

V priebehu opery zaznieva ária dvakrát. Prvýkrát ju autorka predstaví pri vyššie uvedenej udalosti. Druhýkrát zaznieva v momente, ked'do divadla prichádza Dorian, Basil a lord Henry s úmyslom vidiet' herečku, do ktorej sa Dorian zamiloval. Opakovanie tejto árie je totožné s jej prvým uvedením.

\section{Sibyl Vane a Dorian Gray}

Čekovská počas celej opery preferuje dychové nástroje, hlasné údery bicích nástrojov a disonantnú harmóniu. Prvé dueto Sibyl a Doriana má však inú hudobnú podobu. Odohráva sa na začiatku tretej scény v hereckej šatni Sibyl. Po predstavení za ňou prichádza Dorian Gray vyznat’ sa zo svojich citov. Inštrumentácia je jednoduchá, jemná, necháva vyniknút spev (vyznanie lásky): vokálne party hlavných postáv sú sprevádzané len rytmicky málo pohyblivou melódiou kontrabasov a violončiel obohatenou priezračným timbrom xylofónu a flauty. V opere je lúbostné dueto Doriana a Sibyl jediným číslom, kde dominujú sláčikové nástroje nad dychovými. Jediný výrazný dychový nástroj v tejto scéne je flauta. Lyrické melodické línie fláut prinášajú hlboký pokoj.

Notový príklad 10: Harmónia a inštrumentácia lúbostného dueta ${ }^{116}$

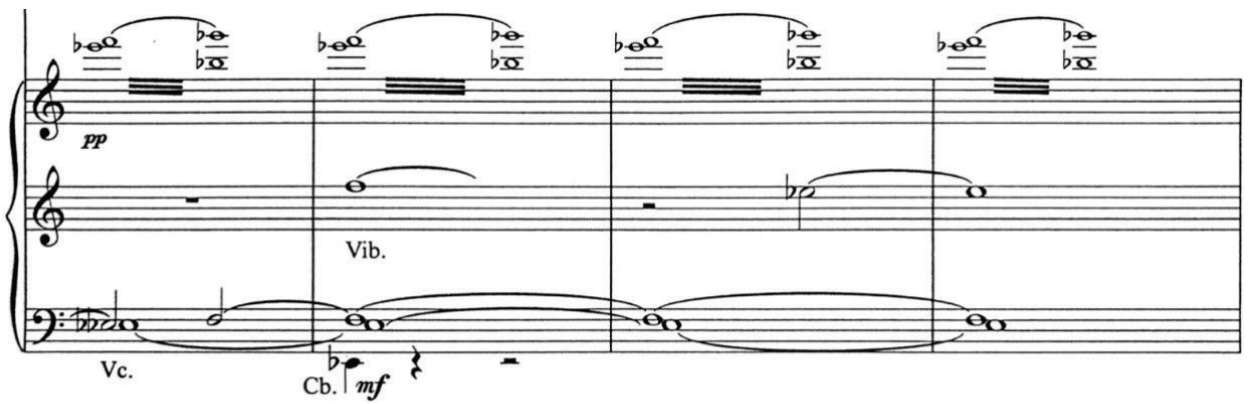

Dynamika dueta s čoraz odvážnejšími vyznaniami lásky narastá a graduje, z úvodného piano prechádza do forte-fortissimo a vrcholí v momente, ked' Sibyl prisl'ubuje 
Dorianovi, že sa stane jeho ženou. To možno chápat’ nasledovne: na začiatku stretnutia je Dorian spolu so Sibyl v rozpakoch. Sú nesmelí presne tak, ako dvaja ludia, čo sa vidia po prvýkrát, ale vedia, že medzi nimi okamžite prebehla iskra a vznikla vášeň. Táto nesmelost' je charakterizovaná aj v hudbe prostredníctvom jej jednoduchosti a jemnosti. S narastajúcou túžbou a vyznaniami lásky „narastá" a silnie aj dynamika. Ked’ sa Dorian a Sibyl rozlúčia, hudba sa opät' "stiahne“ do pôvodnej dynamiky piano.

Notový príklad 11: Vrchol lúbostného dueta ${ }^{117}$

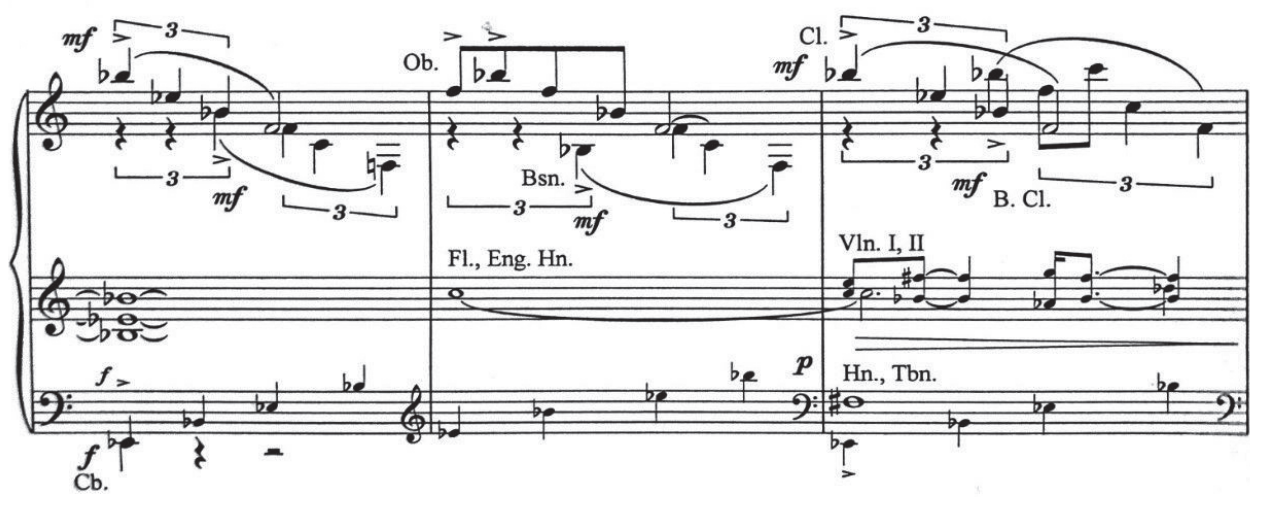

Druhé a zároveň posledné dueto Sibyl a Doriana sa odohráva na začiatku piatej scény. Sklamaný a nahnevaný Dorian prichádza do hereckej šatne Sibyl. Snaží sa jej vysvetlit', ako hrozne ho pred jeho priatel'mi zahanbila. Nechce s ňou mat' už nič spoločné. Zakazuje jej dotýkat’ sa ho. Sibyl nerozumie, čo sa deje a prečo ju Dorian odmieta. Presviedča Doriana, že už nedokáže hrat' dobre, pretože v umení viac nevidí zmysel. Záleží jej jedine na ich láske.

Bol však Dorian do Sibyl skutočne zamilovaný? Lord Henry od začiatku vplýval na Doriana najmä svojou životnou filozofiou „nepremárnit život“. Neraz opakoval, že pokušeniu sa dá odolat’ jedine tak, že mu človek podlahne. Dorianovi sa táto filozofia zapáčila a mala na neho okamžitý účinok. Je teda možné, že by Dorian namiesto života plného zábavy a hedonizmu uprednostnil život po boku jedinej ženy? Dokáže Dorian pod Henryho vplyvom skutočne milovat’ jednu ženu? Už pri prvom stretnutí ospevuje Dorian nie samotnú Sibyl, ale jej dramatické divadelné postavy, ktoré sú pre neho očarujúce.

"Night after night, I watch you perform, when I close my eyes I hear your voice. You are Juliet, and Rosalind, and Imogen And tonight!, my Ophelia." ${ }^{118}$
[Noc čo noc sledujem ta hrat', ked'zavriem oči, počujem tvoj hlas. Si Júlia, Rozalinda a Imogen.

A dnes večer!, moja Ofélia.] ${ }^{119}$

Vzápätí vyslovuje: "You will marry me. You will be my wife." ${ }^{120}$ [Vezmeš si ma. Budeš mojou manželkou.]. ${ }^{121} Z$ jeho slov vyplýva, že Sibyl pre Doriana predstavuje stelesnenie viacerých žien $v$ jednej osobe, a preto ho na začiatku tak vel'mi priţahuje. V skutočnosti ju však nemiluje pravou láskou. Lord Henry oznamuje Dorianovi, že Sibyl síce krásna je, ale hrat’ nevie. V momente, ked' si Dorian uvedomí, že Sibyl prestala byt' herečkou a stala sa len „jednou“ ženou, rozhodne sa ju opustit”. 
"I loved you because you were marvellous. Juliet, Rosalind, Ophelia, You have thrown all that away.

Don't touch me!

I can't see you again.

You have bored my friends,

You have humiliated me."122
[„Lúbil som t’a, lebo si bola famózna;

Júlia, Rozalinda, Ofélia, všetko si to zahodila.

Nedotýkaj sa ma!

Už tá nechcem vidiet'.

Znudila si mojich priatelov.

Ponížila si ma.." ${ }^{123}$

Je zrejmé, že Sibyl Doriana skutočne milovala. Kým sa s Dorianom nestretla, nepoznala nič iné, len svet umenia. Umenie bolo jej životom. Lásku a muža poznala len prostredníctvom divadla a dramatických postáv ako je Júlia, Rosalinda či Ofélia. Ked'však prichádza Dorian, Sibyl spoznáva, čo je skutočný cit:„But you have given me something higher than Art. You are more to me than Art can ever be. I have grown sick of shadows. Your love has brought me into the light." ${ }^{124}$ [No ty si mi dal čosi vyššie, ako umenie. Si pre mňa viac, ako hocaké umenie. Tvoja láska priviedla ma ku svetlu]. ${ }^{125}$ Dorian pre ňu predstavoval stelesnenie krásy: „The world is changed because you are made of ivory and gold." ${ }^{126}$ [Svet sa zmenil, pretože si učinený zo zlata a slonoviny]. ${ }^{127}$ Ked' ju Dorian opustí a ona si uvedomí, že hrat' už viac nedokáže, nevidí viac zmysel d'alej žit'.

Počas druhého dueta sa znovu objavujú trioly harfy. V tmavom orchestrálnom zvuku ich však tažko rozoznat'. Po celý čas znie pravidelná metrorytmická pulzácia, čo u poslucháča môže evokovat' zvuk metronómu, odpočítavajúci čas do následnej tragickej udalosti - samovraždy Sibyl. Ďalšia zaujímavá čast' tohto dueta prichádza v momente, ked'Dorian vysvetluje Sibyl, že sa do nej zamiloval preto, lebo bola famóznou herečkou. Tremolo v malej tercii akoby evokovalo zlé očakávanie.

Smrt' Sibyl hudobne sprevádzajú nástroje, po celú dobu pre ňu charakteristické harfa a vibrafón. V harmónii zaznievajú dlho držané tercie sláčikových nástrojov. Sibyl naposledy zopakuje „... svet sa zmenil, pretože si učinený zo zlata a slonoviny" a svoj výstup ukončuje skokom $z$ tónu $e^{2}$ na tón $a^{2} v$ mezzoforte, čo u poslucháča môže evokovat' posledný zúfalý výkrik Sibyl. Sibyl vypije jed a umiera.

Notový príklad 12: Záverečné tóny Siby| ${ }^{128}$
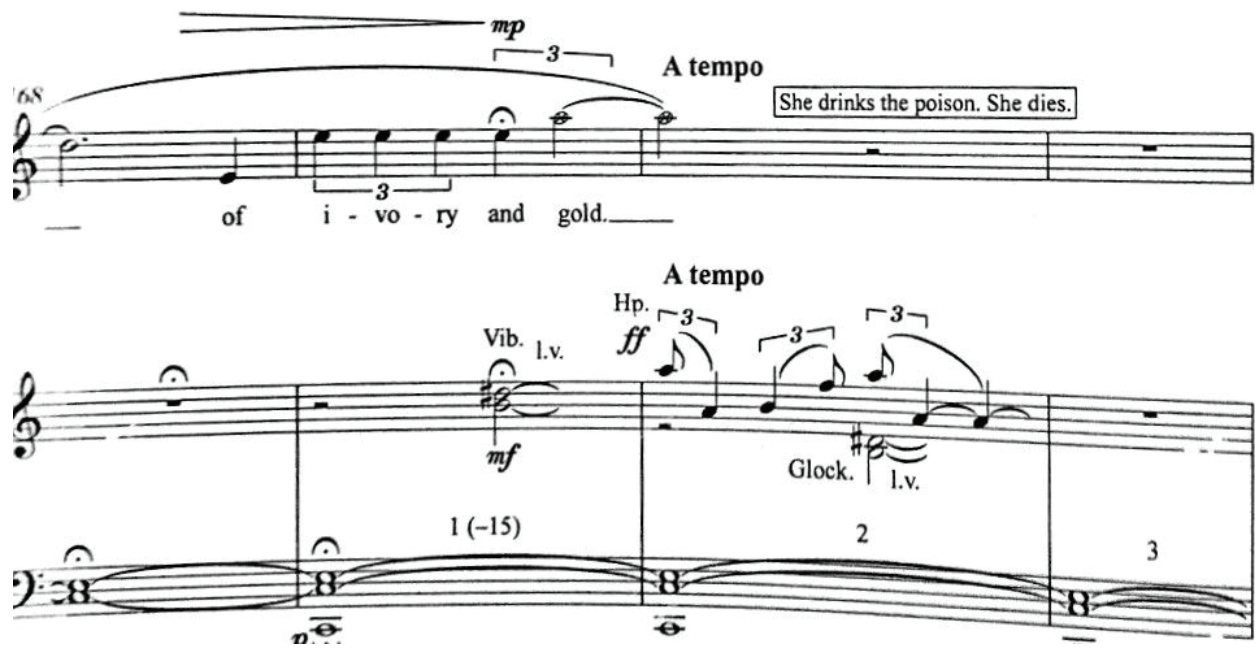
Henry Wotton

Lord Henry Wotton je šlachtic, oblúbený účastník večierkov vyššej anglickej spoločnosti a vynikajúci rečník. Dorian ho okúzli už pri ich prvom stretnutí a následne sa z nich stanú dobrí priatelia. Rovnako ako v knižnej predlohe, tak ani v librete nemožno popriet' vplyv lorda Henryho na Doriana Graya.

V rámci hlasového zaradenia pre neho skladatel'ka zvolila barytón. ${ }^{129}$ Vokálny part lorda Henryho sa pohybuje v rozsahu e po $f^{\prime}$. Zväčša však Henry spieva medzi $h$ a $f^{\prime}$, čo je v porovnaní s vokálnym partom Doriana ovel'a menší intervalový rozsah. To môže mat’ svoju symboliku: lord Henry je muž, ktorého povaha je pokojná. Lord Henry v priebehu takmer celej opery nemení emócie: nie je nahnevaný, ani štastný, je neutrálny. Preto je aj jeho vokálny part z hladiska intervalových skokov menej pohyblivý, technicky nenáročný. Práve svojím pokojným, ale presvedčivým prednesom Wotton dodáva svojej životnej filozofii skutočnú dôveryhodnost'.

Lord Henry sa objavuje hned'v prvom dejstve, v prvej scéne, ked'chváli Basilov portrét. Dorian prichádza do ateliéru a Basil zoznamuje lorda Henryho s Dorianom. V tomto momente sa v harmónii po prvýkrát objaví klaster. Do tejto chvíle nebola harmónia výrazne disonantná. Náhly zhluk tónov môže byt' predzvest'ou náhlej zmeny: tak ako sa v harmónii nečakane objaví príkry zhluk, aj Dorian svojou zmenou prejde ostro, a to okamžite po zoznámení sa s lordom Henrym. Čekovská tak už pravdepodobne na tomto mieste svojim divákom prezrádza, že ich zoznámenie bude mat’ závažné následky.

Notový príklad 13: Klaster v harmónii ${ }^{130}$

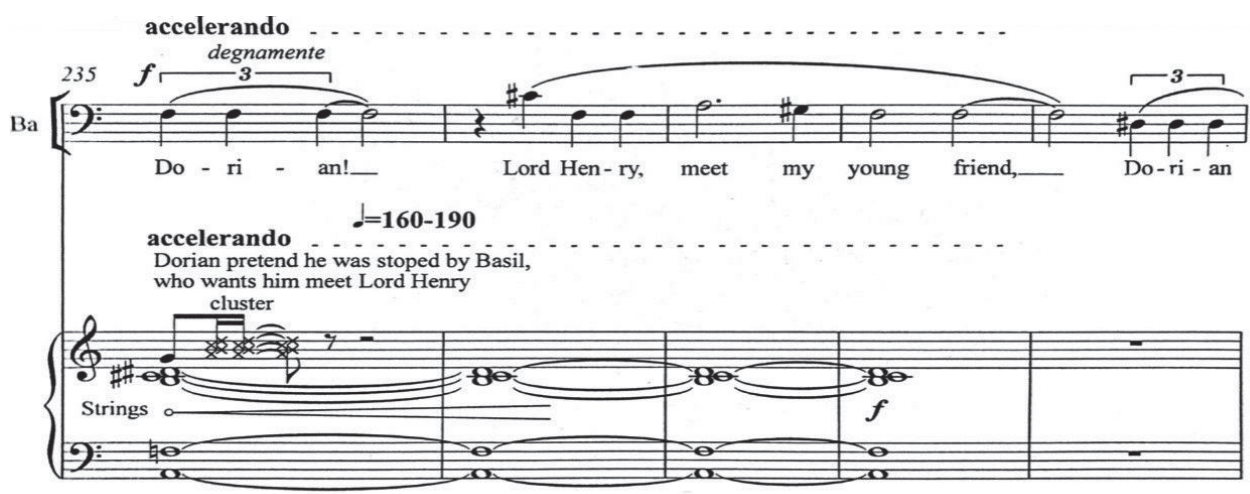

Lord Henry Dorianovi rozpráva o dokonalom živote plnom hedonizmu. Tvrdí, že: "The only way to get rid of temptation is to yield to it." ${ }^{131}$ [Jediný spôsob, ako sa zbavit' pokušenia, je podlahnút' mu]. ${ }^{132}$ Basil si zámer lorda Henryho okamžite uvedomí a snaží sa Doriana varovat'. Tu prichádza krátka hudobná čast' - terceto - lorda Henryho, Doriana a Basila. Basil spieva: „I've put too much of myself in this painting. I've put everything I have into this painting. ${ }^{133}$ [Dal som do toho obrazu príliš vela zo seba. Do tohto obrazu som vložil všetko, čo mám]. ${ }^{134} \mathrm{~V}$ Dorianovom vokálnom parte zaznieva otázka: „Is he such a bad influence Basil? I do so long to be entertained."135 [Má taký zlý vplyv, Bazil? Ja sa tak túžim zabávat..] ${ }^{136}$ Lord Henry do terceta prispieva zdôrazňovaním Dorianovej krásy: „You are so young, you are perfect..137 
[Ste taký mladý, taký dokonalý]. ${ }^{138}$ Slová lorda Henryho o spôsobe života, ktorý nepozná nudu, majú na Doriana okamžitý účinok. Hoci mierne zaváha, rozhodne sa žit život podla lorda Henryho Wottona. Ich vokálne party sú počas spievania bez orchestrálneho sprievodu, ale v momente, ked' spievat’ prestanú, sa v harmónii po prvýkrát objaví ostinátne opakovaný tón - „metronóm času“. Na tomto mieste sa teda „metronóm času“ spustí a objavuje sa po zvyšok opery, až kým sa nezastaví v momente Dorianovej smrti.

Ked'sa z Doriana stane pomätený človek, Henry ho opustí. Nemožno ho tak považovat' za skutočného Dorianovho priatel'a. Akonáhle Dorian prestal byt’ dobrou partiou, lord Henry prestal vyhl'adávat' jeho spoločnost'.

\section{Basil Hallward}

Podobne ako ostatné postavy, ani dramatický hrdina Hallward sa zásadným spôsobom neodlišuje od rovnomennej postavy v románe. Skladatel'ka pre neho zvolila hlas basbarytón. ${ }^{139}$ Vokálny part Basila sa pohybuje v rozsahu od Gis po $e^{1}$.

Najvýraznejším momentom týkajúcim sa Basila v rámci celej opery je situácia, ked' prichádza za Dorianom s úmyslom opýtat' sa ho na jeho hrôzostrašnú povest'. Basil sa z rečí Dorianovych známych dozvedel, že je podlý a zlomysel’ný. Vraj sa mu hriech vpisuje do tváre. Túži zistit', čo sa s ním stalo: „Know you? I wonder do I know you? Before I can answer that, I should have to see your soul." 140 [Poznat' ta? Ktovie, či t’a poznám. Aby som to vedel zodpovedat', musel by som vidiet' tvoju dušu]. ${ }^{141}$ To Doriana nahnevá a rozhodne sa mu ukázat' hriechmi zdeformovaný portrét: „Each of us has Heaven and Hell in him. Sin is a thing that writes itself across a man's face. "142 [Každý z nás nosí v sebe nebo aj peklo. Hriech sa vpisuje do ludskej tváre.] ${ }^{143}$ Dorian stiahne plachtu z obrazu, Basil je zhrozený tým, čo vidí. Pochopí, že Dorian je ovel'a horší, ako o ňom ludia hovoria. Basilove posledné slová znejú: „I worshipped you too much. We are both punished." ${ }^{144}$ [Príliš som táa obdivoval. Obaja sme potrestaní.] $]^{145}$

Notový príklad 14: Záverečná fráza Basila a glissandá trombónov ${ }^{146}$

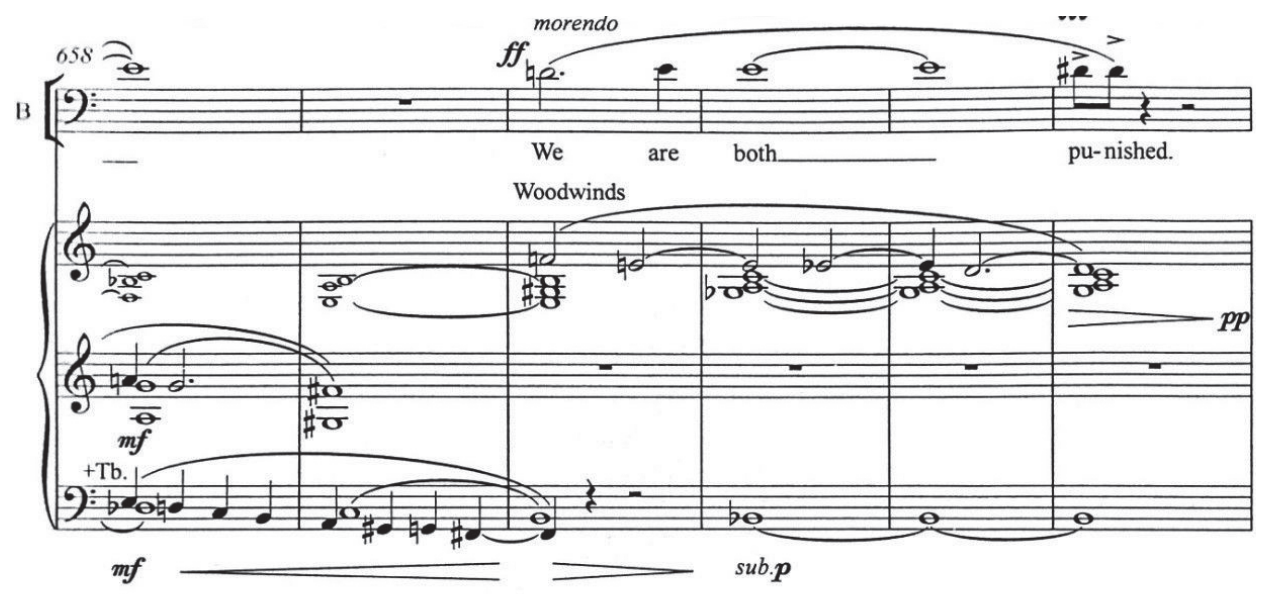




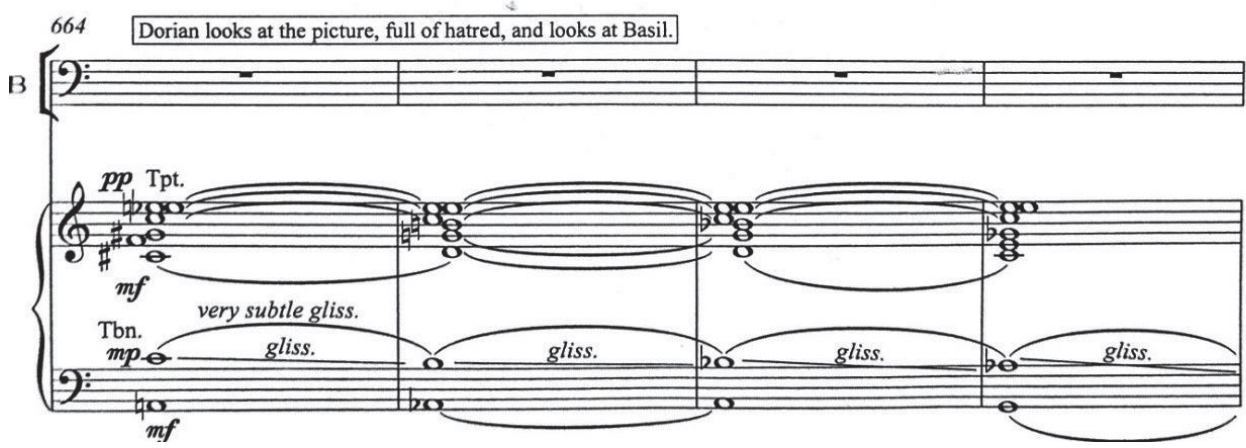

Tieto slová ukončuje Basil najskôr na vel'kej sekunde $d^{1}-e^{1}$, a následne smerom nadol na malej sekunde $e^{1}-d i s^{1}$. Sú to najvyššie tóny, ktoré doteraz zaspieval. Túto čast' umocňuje aj dynamika vo fortissimo. Takáto kombinácia môže u poslucháča evokovat' pocity hrôzy, zdesenia a strachu zároveň. Následne v harmónii zaznievajú glissandá trombónov, ktoré tieto pocity ešte viac umocnia. Dorian Basila zavraždí.

\section{Záver}

Estét a kritik spoločnosti Oscar Wilde patrí medzi najvýznamnejších dekadentných spisovatelov viktoriánskej doby. Jeho jediný román Portrét Doriana Graya prináša tému posadnutosti mladostou a krásou, ako aj tému ludskej márnivosti a deštrukcie ludskej duše. Nesie znaky faustovskej tematiky. Príbeh rozpráva o životnej púti človeka, ktorý sa dá zlákat’ svetom plným zábavy, vzrušenia a potešenia. Pre široký okruh umelcov sa Portrét Doriana Graya stal fenoménom, ktorý zvečnili v mnohých umeleckých dielach.

Hrdinom analyzovaného diela je Dorian Gray. Je to mladý aristokrat, nádherný muž, ktorý v jednej z preferovaných londýnskych štvrtí zdedí dom po svojom starom otcovi. Do deja vstupuje ako čistá duša, „nepopísaný papier“. Stretnutie s lordom Henrym, ktorý ho nabáda na život plný hedonizmu, sa mu stáva fatálnym. Umelec Basil Hallward namaluje portrét Dorianovej tváre. Dorian, ktorý sa v portréte spoznáva a uvedomí si svoju krásu, vyslovuje želanie, aby namiesto neho starol portrét a on ostal navždy mladý a krásny. Ponúkne za to svoju dušu. Želanie sa mu vyplní, ale je preňho osudné. Každý jeho hriech sa odrazí na obraze. Portrét sa mení na prehnitý, hriechmi zdeformovaný obraz Dorianovho svedomia. Bodnutím do obrazu chce portrét zničit’ a skončit’ s minulostou. Portrét sa vyčistí, avšak „kúzlo“, vd’aka ktorému ostal tol'ký čas mladý a krásny, sa stráca a hrôzostrašný obraz sa prenáša na výzor samotného Doriana. Zomiera ako starý, zvráskavený muž s odpudivou tvárou.

Toto nadčasové a v súčasnej dobe stále aktuálne dielo predstavuje silný odkaz a zároveň varovanie pre dnešnú populáciu, ktorá je posadnutá mladým a krásnym zovňajškom, bohatstvom a bezstarostným životom. Niet sa teda čo čudovat', že l’ubicu Čekovskú Portrét Doriana Graya zaujal a že sa rozhodla spracovat' tému pre divadelné javisko. 
Opera Dorian Gray je prvou slovenskou operou skomponovanou ženou. Dielo vzbudilo záujem recenzentov z renomovaných zahraničných printových a elektronických médií, ako napríklad The New York Times, Opera New London, Opernwelt a d'alších. Mnohí z recenzentov tvrdia, že toto dielo ambicióznej umelkyne slovenskú hudobnú scénu obohatilo.

Autorka v rámci celej opery využila hudobné témy, vychádzajúce $z$ jedného spoločného hudobného základu, s ktorými pracovala v rôznych hudobných variáciách. $\checkmark$ prvom dejstve autorka hudby skomponovala prehl'adnú harmóniu s využitím dlho znejúcich rytmických hodnôt konsonantných súzvukov. V priebehu druhého a tretieho dejstva prehl'adná harmónia postupne graduje ku klastrom, ostrej disonantnosti, glissandám a neprirodzeným polohám hudobných nástrojov. Výraznou súčastou celého kompozičného jazyka opery sú dlhé, hutné, akordické súzvuky, zväčša vyššej terciovej stavby. Inštrumentácia opery je miestami jednoduchá - často necháva vyniknút' spievané slovo len na podklade komorného orchestrálneho sprievodu, alebo aj bez neho, inokedy je však dramaticky vypätá - zvukovo farebná s prevahou dychových nástrojov a hlasných úderov bicích nástrojov. $V$ priebehu celej opery využíva Čekovská ostinátne opakovanie tónu - metrorytmickú pulzáciu, ktorá u poslucháča môže evokovat' metronóm, ktorý odpočítava čas do naplnenia tragických udalostí: tým myslíme viacnásobnú smrt’ dôležitých postáv. S bližiacou sa smrtou hlavného hrdinu zaznievajú glissandá trombónov a violončiel, ktoré na poslucháča môžu pôsobit' hrozivo.

Hudobno-textovou analýzou opery Dorian Gray sme dospeli k záveru, že tažiskom jej hudobnej reči je pätnásttaktová téma - leitmotív hlavného hrdinu (Hlasy obrazu). Zatial' čo v literárnej predlohe sa s každým Dorianovým hriechom mení podobizeň obrazu, v opere skladatel'ka využila túto hudobnú tému a jej premeny ako metaforu meniaceho sa portrétu. Na javisku sa tak každý jeden Dorianov hriech prejaví v znení témy, ktorá na seba postupne s každým hriechom „nabaluje“ čoraz komplikovanejšiu podobu, až vrcholí v démonickom znení plnom glissánd.

Dielo neobsahuje číslované árie $v$ zmysle staršej opernej tradície. Jednotlivé hudobné čísla sa sústred'ujú najmä na postavu Doriana Graya, ktorý neopustí scénu v priebehu takmer celej opery. Jeho vokálny part je spevácky náročný, obsahuje pestrú prednesovú škálu, zväčša sa pohybuje v rozsahu od $e^{2}$ po $h i^{2}$. Vokálne party jednotlivých postáv opery sú často ukončované skokom na vysoký tón - a to najmä vo vyhrotených situáciách, ked' sú postavy zúfalé. Najmä v závere opery necháva autorka hudby jednotlivé miesta Dorianovho vokálneho partu bez orchestrálneho sprievodu pravdepodobne preto, aby umocnila fakt, že ostal sám.

Portrét Doriana Graya je často rozoberanou témou mnohých autorov. Napriek tomu sa centrum záujmu autorov sústreduje prevažne na jednotlivé postavy - vztahy medzi nimi akoby s charakterom postáv nesúviseli. Pri zostavovaní metodiky našej práce a pri jej aplikácii sme $v$ duchu publikácií venujúcich sa definícii pojmu charakter postáv potvrdili predpoklad, že dôležitým faktorom je aj analýza vzt’ahov medzi postavami.

Analýzou postáv a vztahov medzi nimi sme dospeli k záveru, že jednotlivé operné postavy sú totožné s románovými postavami. Libretistka opery Kate Pullingerová podstatu diela zachovala, vybrala z neho najpodstatnejšie momenty a dramatické 
situácie. Vytvorila tak pútavý operný dej. Medzi literárnou predlohou a libretom opery nachádzame niekol'ko drobných námetových posunov, tie však nijako výrazne dej nemenia. Výraznou zmenou je však záver príbehu. Zatial' čo v literárnej predlohe sa dej končí tým, že sluhovia nájdu mŕtve zvráskavené telo Doriana Graya, v librete vstupuje slúžka Mrs. Leaf do vyčistenej prázdnej izby, v ktorej Dorian zomrel. Táto scéna prináša náznak nádeje. Práve počas nej využila Čekovská farebne pestrý symfonický epilóg, s použitím akordov vyššej terciovej stavby. Dynamiku piano v závere symfonického epilógu (taktiež $p p, p p p, p p p$ ) a doznievanie akordov možno chápat’ ako zámer autorky nechat' divákom otvorený priestor premýšlat', či si Dorian zaslúži odpustenie.

POZNÁMKY

1 Dekadencia pochádza z francúzskeho slova décadénce - úpadok. Je to umelecký smer z prelomu 19. a 20. storočia. Zálubu nachádza v stvárňovaní či vyjadrovaní nálad smútku, pesimizmu, skepsy, nudy, márnosti až opovrhovania životom. Taktiež odhaluje najviac tabuizované témy, ako je homosexualita či satanizmus.

2 MOJŽIŠOVÁ, Michaela: Vyliečit dušu vd’aka svojim zmyslom a vd'aka duši vyliečit' si zmysly. [Online.] 2013. [Cit. 2013-09-08]. Dostupné na: https://www.monitoringdivadiel.sk/ recenzie/recenzia/vyliecit-dusu-vdaka-svojimzmyslom-a-vdaka-dusi-vyliecit-si-zmysly/

3 Príbeh o doktorovi Faustovi a jeho zmluve $s$ diablom je od 16. storočia jedným z najčastejšie spracovávaných námetov v európskej literatúre. Predlohou pre postavu doktora Fausta bol Johann Georg Faust (1480 - 1540), potulný alchymista, o ktorom už počas jeho života kolovali reči, že sa spolčil s diablom.

4 Hedonizmus je filozofický smer a etické učenie, podl'a ktorého je dobro to, čo lud'om poskytuje rozkoš, alebo ich zbavuje utrpenia.

5 SKILTON, David: The Early and Mid-Victorian Novel. London: Routledge, 1993, s. 182.

6 STŘíBRNÝ, Zdeněk: Dějiny anglické literatury 2. Praha: Academia, 1987, s. 837.

7 MOCNÁ, Dagmar - PETERKA, Josef: Encyklopedie literárních žánrů. Praha: Paseka, 2004, s. 630 - 631.

8 ŠMEJDOVÁ, Petra: Dekadentní literatura. [Online.] 2009. [Cit. 2009-10-18]. Dostupné na: https://www.vaseliteratura.cz/dejiny-literatury/706-dekadentni-literatura

9 ELLMANN, Richard: Oscar Wilde. London: Vintage, 2013, s. 256.
10 ELLMANN, c. d., 2013, s. 434.

11 ELLMANN, c. d., 2013, s. 420.

12 SIMKIN, John: John Gray. [Online.] 2020. [Cit. 2020-01-03]. Dostupné na: https:// spartacus-educational.com/WILDgray.htm

13 WILDE, Oscar: Portrét Doriana Graya. Prel. Tatjana Ruppeldtová. Bratislava: Petit Press, 2004, s. 6.

14 MACCHARTY, Fiona: Falling out with Oscar. [Online.] 2008. [Cit. 2008-08-30]. Dostupné na: https://www.theguardian.com/stage/2008/aug/30/matthewbourne.wilde

15 MARTIN, Andrew: The Inspiration for The Picture of Dorian Gray: Oscar Wilde and Robert Browning. [Online.] 2015. [Cit. 2015-03-19]. Dostupné na: https://thosepassionsread.wordpress.com/2015/03/19/ the-inspiration-for-the-picture-ofdorian-gray-oscar-wilde-and-robert-browning/

16 ELLMANN, c. d., 2013, s. 450.

17 PROCHÁZKA, Martin - STŘíBRNÝ, Zdeněk: Slovník spisovatelů : anglická literatura : africké literatury $v$ angličtine. Praha: Libri, 1996, s. 756.

18 ROSOVÁ, Michaela: Dandy. [Online.] 2012. [Cit. 2012-01-25]. Dostupné na: https:// www.litcentrum.sk/recenzia/dandy-michaela-rosova-zvlastne-svety-v-berline

19 ROSOVÁ, c. d., 2012.

20 „Er-forma“ je forma rozprávania v 3. osobe. Rozprávač je nezaujatým pozorovatel'om príbehu deja.

21 WILDE, c. d., 2004, s. 30.

22 WILDE, c. d., 2004, s. 35.

23 WILDE, c. d., 2004, s. 274.

24 WILDE, c. d., 2004, s. 278.

25 WILDE, c. d., 2004, s. 31.

26 WILDE, c. d., 2004, s. 27.

27 WILDE, c. d., 2004, s. 13. 
38 VONGREJ, L'udovít: Svetová premiéra opery Dorian Gray L'ubice Čekovskej na javisku opery SND. [Online.] Portál Opera Slovakia, 2013, [Cit. 2017-11-15].

39 SMOLÍK, Pavol: Lubica Čekovská: Dorian Gray. In: Impulz. Revue pre modernú katolícku kultúru, roč. 9, 2013, č. 3 - 4. [Online.] [Cit. 2020-03-04.] Dostupné na: http:// www.impulzrevue.sk/article.php?1075 jazyku, aj mená postáv si zachovávajú anglickú formu, ktorú tu nebudeme poslovenčovat'.

49 V pôvodnom románe Portrét Doriana Graya vyzýva lord Henry maliara Basila, aby dielo poslal do Grosvenorskej galérie. V librete je však zmena - lord Henry vyzýva maliara Basila poslat' dielo Akadémii. L'ubice Čekovskej zaujala aj svet. [Online.] 2013. [Cit. 2017-11-18.] Dostupné na: https://www.webnoviny.sk/opera-dorian-grayod-lubice-cekovskej-zaujala-aj-svet

51 EDITORI WEBNOVÍN, c. d., 2013.

52 EDITORI WEBNOVÍN, c. d., 2013.

53 EDITORI WEBNOVÍN, c. d., 2013.

54 MOJŽIŠOVÁ, c. d., 2013, s. 28. hlasovej výchovy (Ružomberok: Verbum, 2015, s. 105) charakterizuje tenor ako vysoký mužský hlas. Jednotlivé tenory rozdeluje nasledovne: (1) lyrický $\left(c-d^{3}\right)$ - má jasné svetlé zafarbenie a svetlé vysoké tóny, je tiež vel'mi pohyblivý. (2) Lyricko-dramatický, spinto $\left(H-h^{2}\right)$ - tento typ definuje ako farebný hlas s kovovými výškami. (3) Hrdinský $\left(H-C^{3}\right)$ - sa vyznačuje širokou strednou polohou, plnou zvukovostou tmavým až barytónovým zafarbením a intenzívnymi vysokými tónmi. (4) Komický, buffo - $\left(c-a^{2}\right)$ - má spomedzi všetkých tenorov najmenší hlasový rozsah, je svetlejšie zafarbený a l'ahší. Je tiež vel'mi pohyblivý a uplatňuje sa v komických operách.

Basel: Bärenreiter Verlag, 2012, s. 62.

[Online.] 2011. [Cit. 2020-02-18.] [Online.] 2011. [Cit. 2020-02-18.] Prel. Jana Kantorová-Báliková.

63 ČEKOVSKÁ, c. d., 2012, s. 84.

64 ČEKOVSKÁ, c. d., 2012, s. 91.

65 PULLINGER, c. d., 2011.

66 PULLINGER, c. d., 2011.

67 PULLINGER, c. d., 2011.
PULLINGER, c. d., 2011.

ČEKOVSKÁ, c. d., 2012, s. 256.

ČEKOVSKÁ, c. d., 2012, s. 274.

PULLINGER, c. d., 2011.

PULLINGER, c. d., 2011.

PULLINGER, c. d., 2011.

PULLINGER, c. d., 2011.

ČEKOVSKÁ, c. d., 2012, s. 314.

VONGREJ, Svetová premiéra opery..., c. d., 2013.

RUDOLF, Robert: Elektronická komunikácia. [2020-03-30]. (Príloha A.)

URSÍNYOVÁ, c. d., 2013.

ČEKOVSKÁ, c. d., 2012, s. 5.

RUDOLF, c. d., 2020. 
Dvojhlas zboru potvrdený tónom cis v melodickom sopránovom parte, orientuje melódiu témy do tonálneho centra.

Erínye boli v starogréckej mytológii bohyne pomsty, služobníčky boha podsvetia Háda.

RUDOLF, c. d., 2020.

RUDOLF, c. d., 2020.

RUDOLF, c. d., 2020.

RUDOLF, c. d., 2020.

JESENIČOVÁ, Soňa: Elektronická komunikácia. [2020-04-20].

RUDOLF, c. d., 2020.

RUDOLF, c. d., 2020.

JESENIČOVÁ, c. d., 2020.

RUDOLF, c. d., 2020.

RUDOLF, c. d., 2020.

RUDOLF, c. d., 2020.

RUDOLF, c. d., 2020.

JESENIČOVÁ, c. d., 2020.

JESENIČOVÁ, c. d., 2020.

RUDOLF, c. d., 2020.

JESENIČOVÁ, c. d., 2020.

RUDOLF, c. d., 2020.

RUDOLF, c. d., 2020.

RUDOLF, c. d., 2020.

JESENIČOVÁ, c. d., 2020.

RUDOLF, c. d., 2020.

RUDOLF, c. d., 2020.

Miriam Žiarna vo svojej Teórii hlasovej výchovy (c. d., 2015, s. 104) definuje soprán ako najvyšší a najčastejšie vyskytujúci sa ženský hlas. Jednotlivé soprány rozdeluje nasledovne: (1) lyrický $\left(h-c^{3}\right)$ - lahodný, jasný, svietivý, l'ahký, štíhly a kantabilný hlas. (2) Mladodramatický $\left(h-c^{3}\right)-v$ porovnaní s lyrickým sopránom je podla nej menej pohyblivý, ale farebnejší a mäkší. (3) Dramatický $\left(a-c^{3}\right)$ - ten autorka definuje ako vel'mi široký, tmavý a mohutný soprán. (4) Koloratúrny $\left(c^{1}-g^{3}\right)$ - rozdelujúci sa na lyrickú a dramatickú koloratúru, je to pohyblivý, jasný a svietivý hlas, vyžaduje si však bravúrnu spevácku techniku. (5) Subretný $\left(c^{1}-e^{3}\right)$ - opisuje Žiarna ako jasný, mäkký, svetlo zafarbený, lyrický či koloratúrny soprán alebo lyrický mezzosoprán.

PULLINGER, c. d., 2011.

PULLINGER, c. d., 2011.

PULLINGER, c. d., 2011.

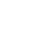
ryton ako mužský hlas ležiaci medzi basom a barytónom. Basbarytón je rozsahovo vyšší ako bas, jeho rozsah sa pohybuje medzi $F-f^{\prime}$.

140 PULLINGER, c. d., 2011.

141 PULLINGER, c. d., 2011.

142 PULLINGER, c. d., 2011.

143 PULLINGER, c. d., 2011.

144 PULLINGER, c. d., 2011.

145 PULLINGER, c. d., 2011.

146 ČEKOVSKÁ, c. d., 2012, s. 256. 


\section{Elektronická komunikácia s Robertom Rudolfom}

\section{Ako prebiehala práca na zvukovej nahrávke témy Hlasy obrazu?}

Práci na zvukových vstupoch pre operu Dorian Gray predchádzali podrobné rozhovory na túto tému s autorkou diela, Ĺubicou Čekovskou. V nich sa postupne kryštalizovala konkrétna podoba jej myšlienky viacerých zvukových predelov s rovnakou tematikou a postupným odklonom od ich pôvodného tvaru. Tá zo začiatku nebola celkom definovaná, ale skladatel'ka pomerne zavčasu svoju predstavu upresňovala, kým mi ju nepredložila v notovej a zvukovej podobe. Pripomínam len, že východiskovým bodom mojej práce bola nahrávka, ktorú realizoval chlapčenský zbor. Na začiatku tvorilo nahrávku sólo chlapčenského sopránu, chlapčenský zbor v jednoduchom sprievode sólovej melódie a oba tieto motívy spojené v jednej nahrávke. Nahrávanie, žial', nespĺňalo požiadavky profesionálneho záznamu z viacerých dôvodov, ktoré nie je potrebné viac rozvádzat'. Z toho však vidiet', že podmienky boli pre autorku i pre mňa od počiatku tažké. Navyše, sólista počas nahrávania začal mutovat’ a tak sa počas neho muselo pristúpit' k náhradným riešeniam, ako bol pokus o výmenu sólistu a s ním pokus o zmenu spôsobu nahrávania.

Po získaní nahrávky a mnohých zásahoch do záznamu, v snahe zabezpečit’ jeho prijatel'nú hudobnú a technickú kvalitu, som predložil výsledky tejto prvej etapy skladatel'ke. Výber padol na konkrétne upravené sólo chlapčenského sopránu a na sprievodný zbor, ako na základný zvukový materiál, od ktorého sa budú odvíjat' variácie.

V druhej etape bolo potrebné vypracovat’ stratégiu, aplikovaním ktorej sa postupné variácie uplatnia $v$ gradácii. S autorkou sme zvolili typ spolupráce, v ktorej mi dala úplne vol'nú ruku, pričom konečné odobrenie každej variácie spočívalo výlučne na nej, čo platilo vždy po vzájomnom rozhovore a argumentácii na tému konkrétnej variácie.

Tému tvorí sólo chlapčenského sopránu so sprievodom chlapčenského zboru. Oba zvukové súbory sú nezávislé a ich dĺžka je upravovaná, takže nezodpovedajú úplne presne pôvodnému notovému zápisu. Tieto malé odchýlky sú spôsobené vyššie spomenutou kvalitou pôvodného materiálu. $V$ tejto fáze bolo potrebné korigovat' intonáciu niektorých miest v sólovom parte aj v zborovom sprievode. Použité programy : Melodyne - Celemony, AutoTune - Antares. V konečnej úprave témy je d’alej použitý program Breverb - Overloud ako reverberačný program na hlavnom výstupe. Je rovnaký pre všetky variácie. Shift a PitchAcc - GRM Tools, sú tu použité ako jemný, sotva počutel'ný delay (oneskorenie signálu), ktorý sa využíva vo väčšej miere v nasledujúcich variáciách.

\section{Vedeli by ste stručne priblížit' technický opis vašej práce s nahrávkou vo vztahu $\mathrm{k}$ variáciám a postupným zmenám pôvodnej témy?}

Var.1

V tejto variácii sa pracuje výhradne so sólovým hlasom, ktorý prechádza delayom (PitchAcc), rozdielnym pre každý stereo kanál a pri nezmenenej výške spievaného tónu. Ciel’om bolo vytvorit’ hlasy mútiace čistotu myšlienok a duše DG, akýsi zvodný hlas „erínyí", ktoré zatial' nemajú príliš vel'ký vplyv na hlavnú postavu.

\section{Var. 2}

V tejto variácii sa k predchádzajúcim úpravám pridáva dynamický (pravdepodobne ručne ovládaný) Shift - GRM Tools. Opät' sa pracuje výhradne so sólovým hlasom, ktorý sa tu posúva vo velmi malých hodnotách, vertikálne aj horizontálne, vo frekvenčnom poli. Dosahuje sa tým mikro ladenie zároveň s filtráciou zvuku. Hodnoty delay sa menia len nepatrne. Toto prvé rozladenie naznačuje váhanie, s akým sa DG potýka. 
Var. 3

Popri už spomenutých efektoch, potlačených viac do úzadia, ale stále prítomných, vstupuje na scénu paralelný transponovaný hlas, ktorý zdanlivo sleduje melodickú líniu témy. Svojím temnejším a zároveň nevtieravo neurčitým, takmer sínusovým timbrom vytvára akýsi tieň. Po technickej stránke ide o interakciu viacerých efektov v presnom zoradení (Doubler a Morphoder - Waves, Harmony Engine - Antares).

Var. 4

V tejto variácii sa prítomnost' tohto tieňa potvrdzuje a spolu s ním sa opät dostáva trochu viac do popredia mikrotonálna transpozícia a delay, vytvárajúci už spomínaný „hlas, či skôr zbor erínyí".

Var. 5

Viacnásobná transpozícia sólového hlasu sa potvrdzuje a s ňou i nastúpená tŕnistá cesta DG. Paralelný hlbšie transponovaný „tieň" prestáva skákat’ v danom intervale cez oktávy a pevnejšie sa spája s líniou pôvodnej melódie, čím ju do istej miery nahrádza. Sprievodný zbor ustupuje do úzadia, i ked'je v prvej časti ešte akoby oporou melodickej línie. V d’alšom priebehu podlieha aj on statickému preladeniu. V deji opery na tomto mieste už DG nie je tým, čím kedysi býval.

Var. 6

V tejto variácii nastáva podstatnejší zlom vo vývine postupných zmien. Pôvodný sólový hlas sa stráca v elektronickom obale. Mení sa jeho základná farba. Timbrálny posun sleduje vývoj osobnosti hlavnej postavy. Rozladenie a delay prechádzajú postupne do prvého plánu a celá variácia je menej neurčitá, zmeny sa stávajú kompaktnejšími.

Var. 7

Melodická línia sa pod nánosom akumulovaných efektov, ako je transpozícia, namnoženie hlasov, delay a dalšie úpravy, úplne stráca. Sprievodný zbor úplne absentuje. Na jeho mieste sa objavuje nový prvok v podobe elektronicky vygenerovaného šepotu. (Pozn. Tento prvok je skôr farebným doplnkom a náhradou zborového podkladu. Jeho použitie je na želanie autorky pomerne potlačené do úzadia.) Masa preladených hlasov vytvára celkom odlišnú melodickú štruktúru, pričom si zachováva relatívnu prehladnost', čo napomáha úplné nahradenie pôvodnej melódie sólového hlasu.

Var. 8

Pridaný elektronický šepot krátko uvádza túto variáciu, v ktorej sa masa delayovaných hlasov prečistí tak, že jednotlivé melodické línie získavajú na samostatnosti. Sledujú celkom nezávislé harmonické smery a pôvodné nahromadenie transponovaných hlasov je potlačené do úzadia. Ich farba sa zároveň mení a je ochudobnená o charakteristický rozmer ludského hlasu filtráciou. Výsledkom je napoly elektronický, napoly ludský zvuk, ktorý spolu s už spomenutým šepotom dotvárajú premenu DG.

\section{Var. 9}

Záverečná variácia je o niečo dlhšia a prináša do procesu postupných zmien nový prvok. Je ním elektronická úprava melódie sólového hlasu, ktorá znižuje jeho pôvodnú kvalitu, v dôsledku čoho sa v ňom objavujú akustické parazity. Úvodom sa opät’ objaví šepot, a následne sa takto upravená pôvodná melodická línia opät dostáva do popredia. Zvádza súboj s predchádzajúcimi premenami, transpozíciami a inými prvkami, ktoré sa v procese už objavili. Jej pôvodná verzia je stále $v$ úzadí a v druhej polovici variácie sa vyvinie do popredia, aby nakoniec v závere dominovala. Štruktúra tejto variácie je trochu odlišná, je o niečo viac spojená s dejom a záverečnou javiskovou akciou. 


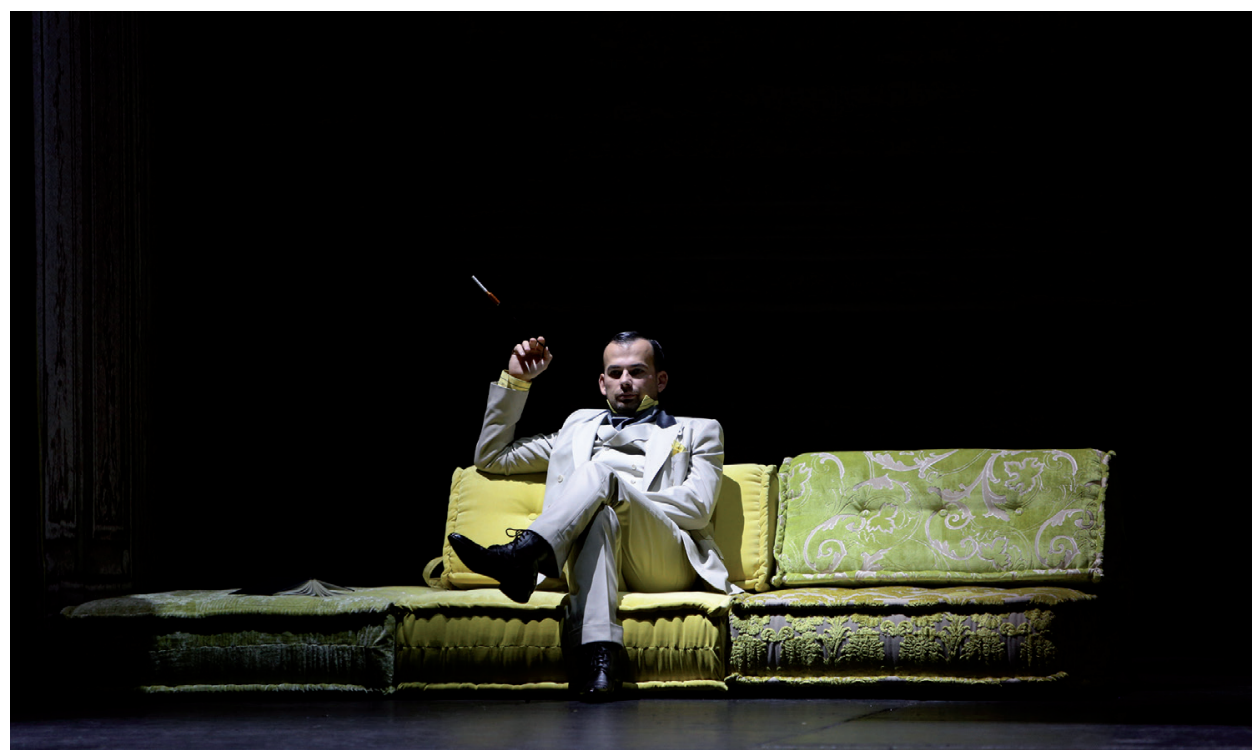

Obr. 1: Dorian Gray - Aleš Jenis (lord Henry). Opera SND, 2013.

Zdroj: Archív SND

Foto: Jozef Barinka

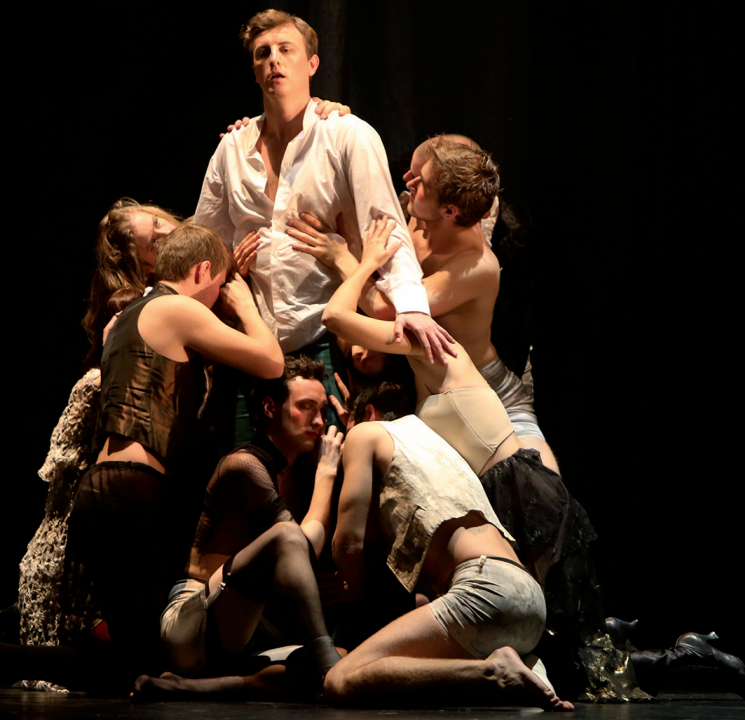

Obr. 2: Dorian Gray - Eamonn Mulhall (Dorian Gray). Opera SND, 2013.

Zdroj: Archív SND

Foto: Jozef Barinka 


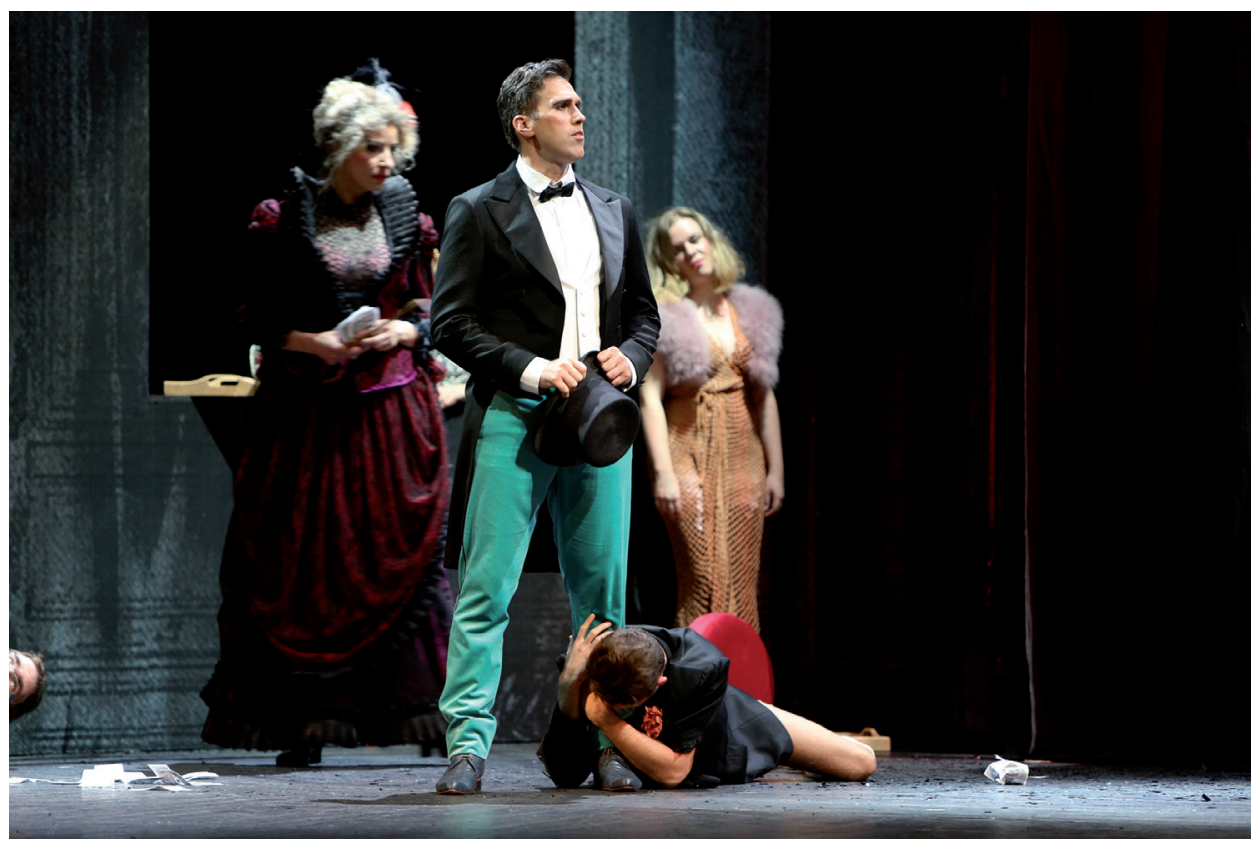

Obr. 3: Dorian Gray - Denisa Hamarová (Bordelmama), Eric Fennell (Dorian Gray). Opera SND, 2013. Zdroj: Archív SND Foto: Jozef Barinka

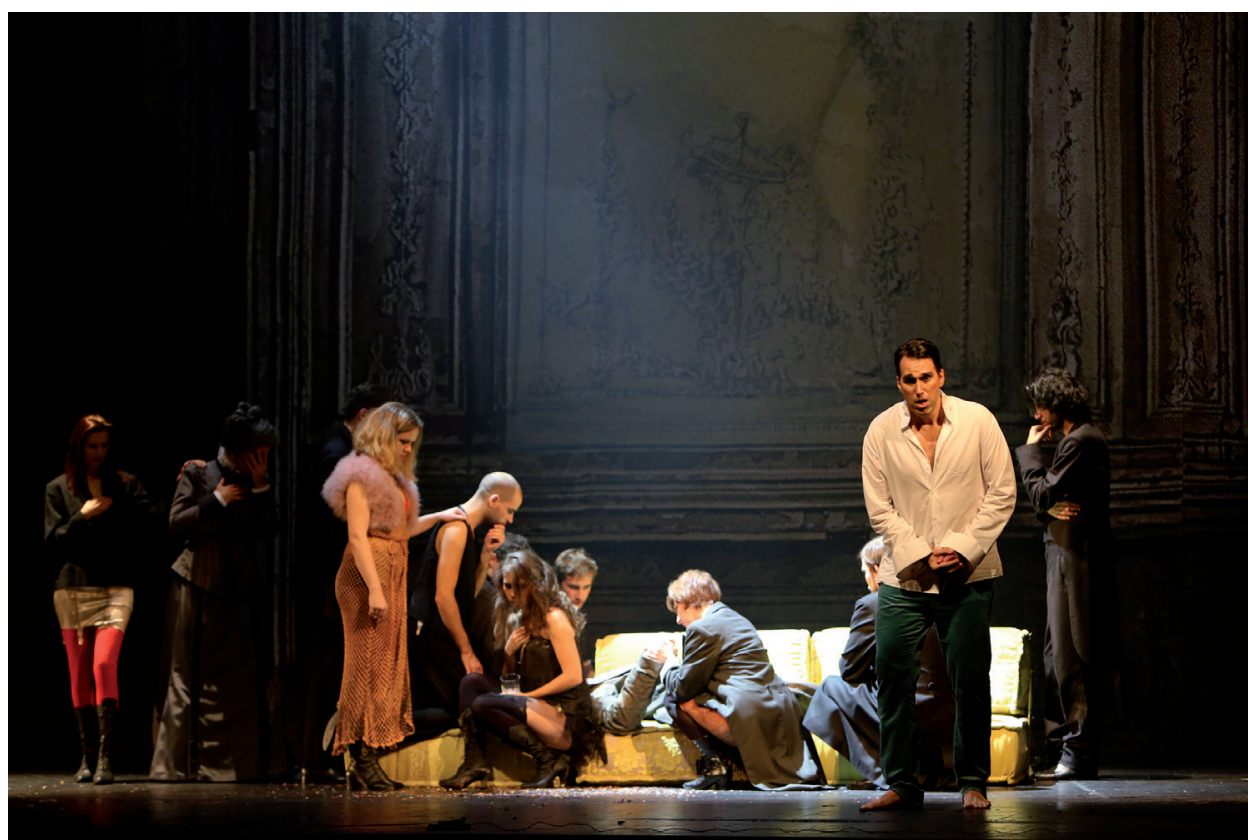

Obr. 4: Dorian Gray - Eric Fennell (Dorian Gray). Opera SND, 2013.

Zdroj: Archív SND

Foto: Jozef Barinka 


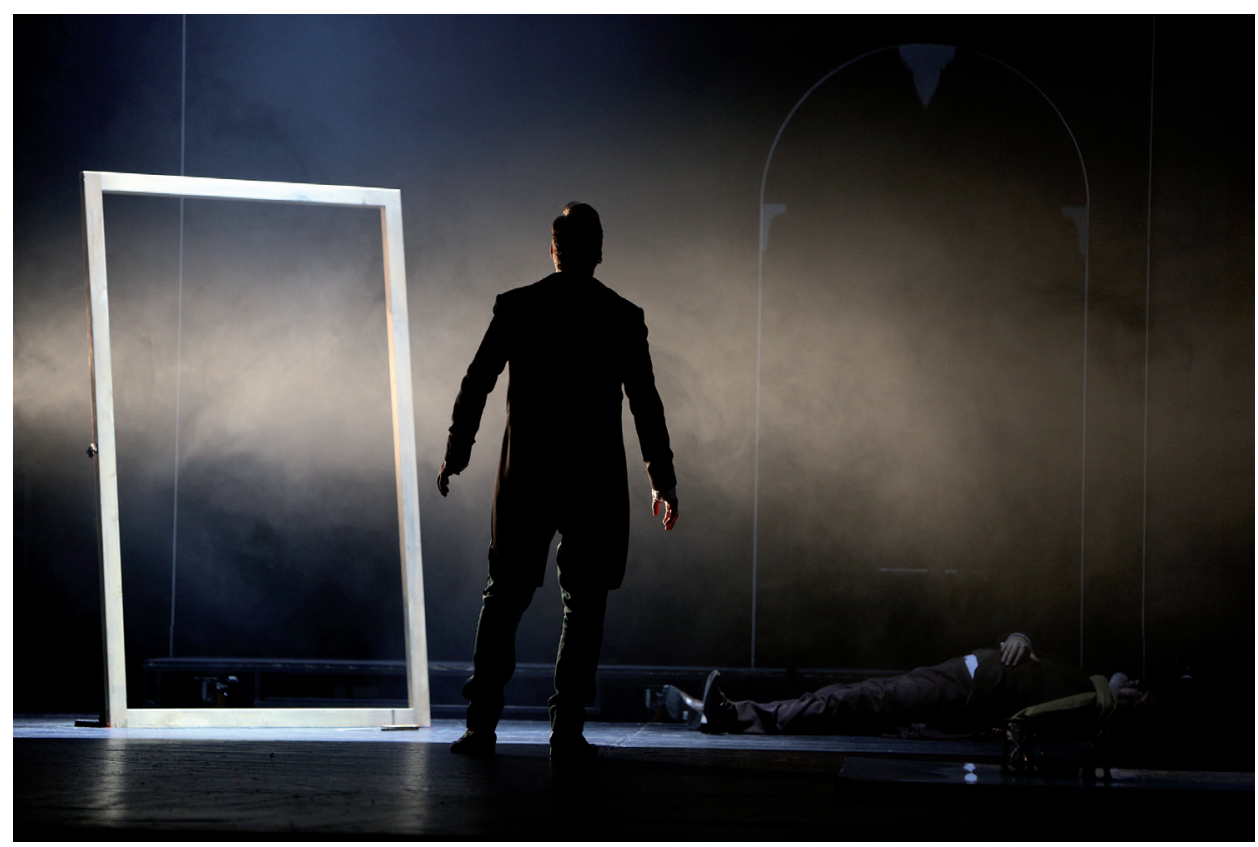

Obr. 5: Dorian Gray - Eric Fennell (Dorian Gray). Opera SND, 2013.

Zdroj: Archív SND

Foto: Jozef Barinka

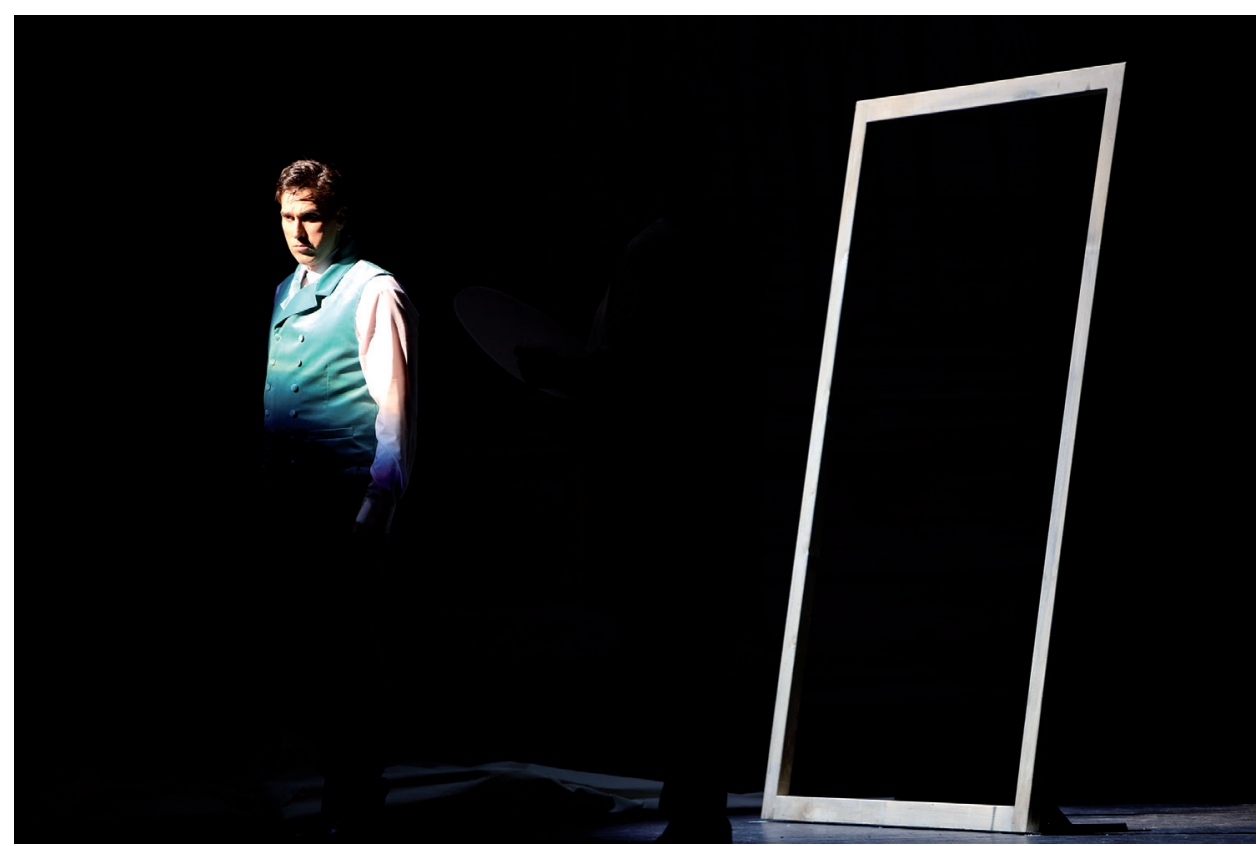

Obr. 6: Dorian Gray - Eric Fennell (Dorian Gray). Opera SND, 2013.

Zdroj: Archív SND

Foto: Jozef Barinka 


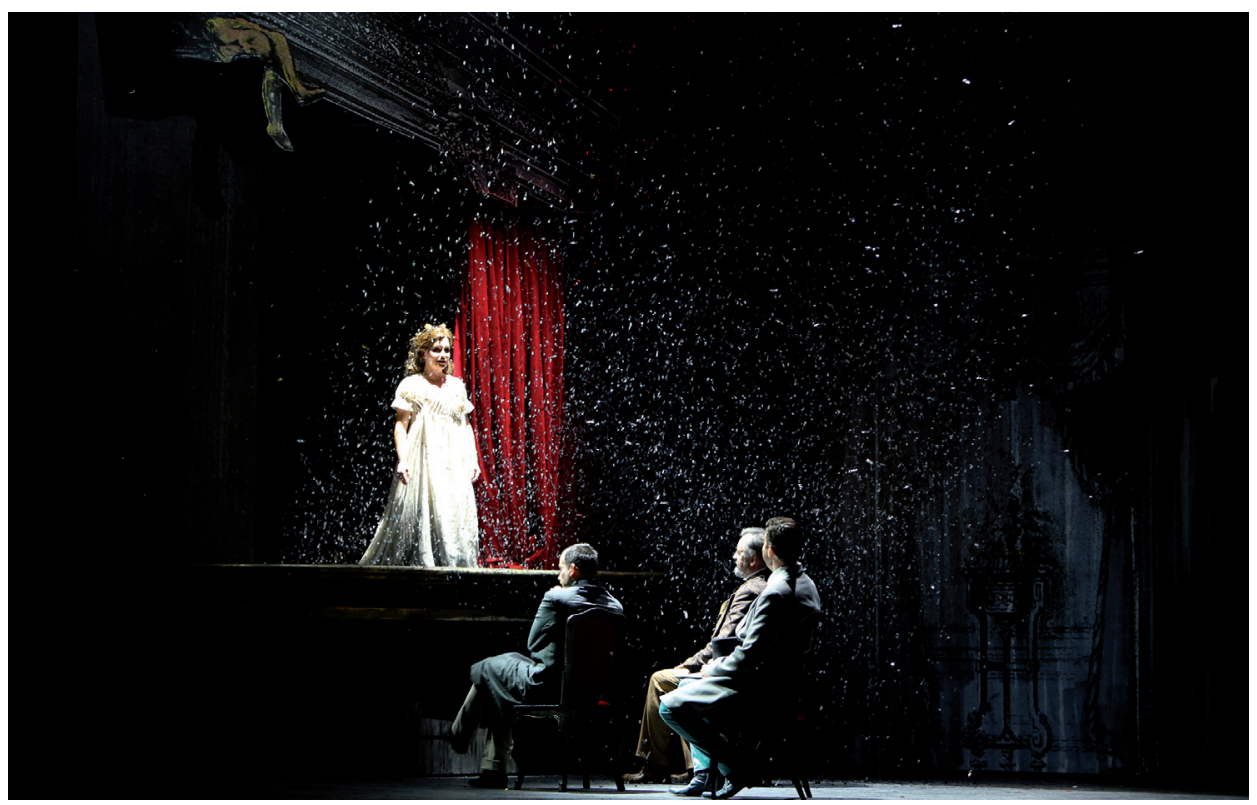

Obr. 7: Dorian Gray - Katarína Juhásová-Štúrová (Sibyl Vane), Aleš Jenis (lord Henry), Ján Galla (Basil Hallward), Eric Fennell (Dorian Gray). Opera SND, 2013.

Zdroj: Archív SND

Foto: Jozef Barinka

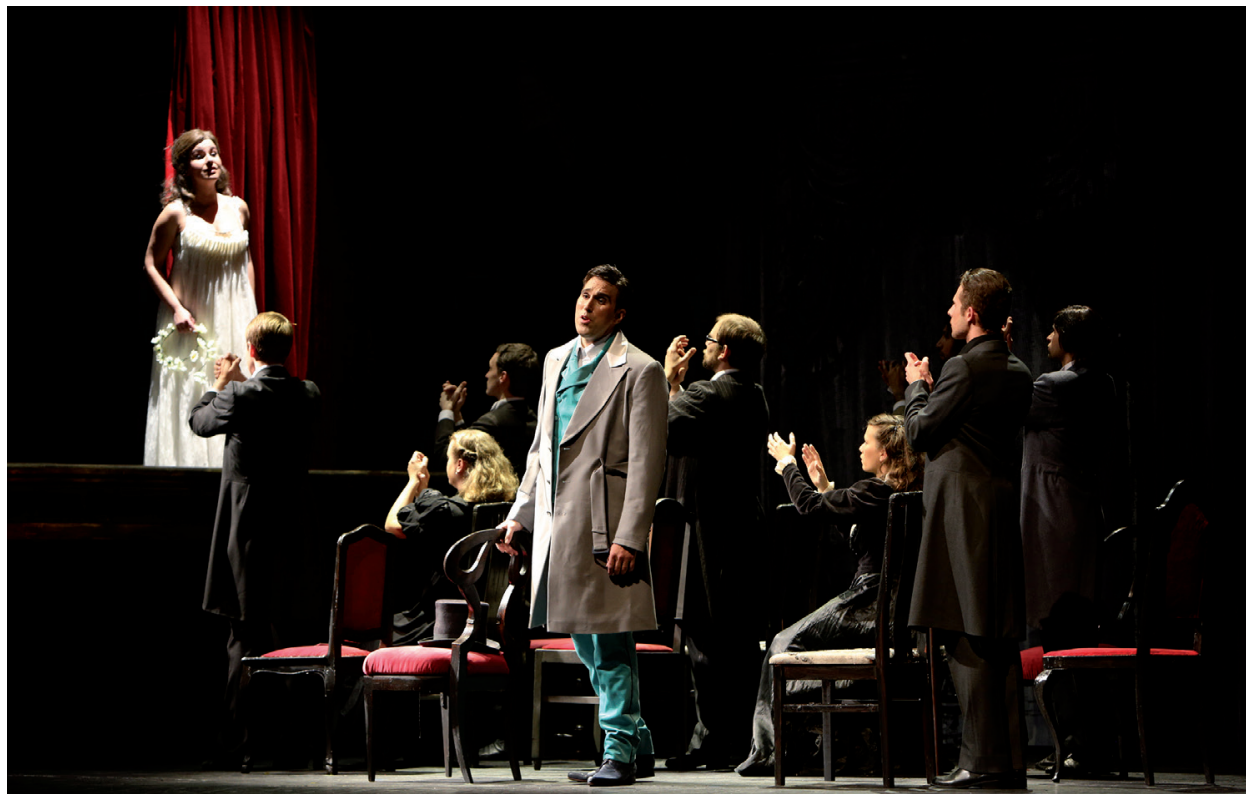

Obr. 8: Dorian Gray - Katarína Juhásová-Štúrová (Sibyl Vane), Eric Fennell (Dorian Gray). Opera SND, 2013.

Zdroj: Archív SND

Foto: Jozef Barinka 


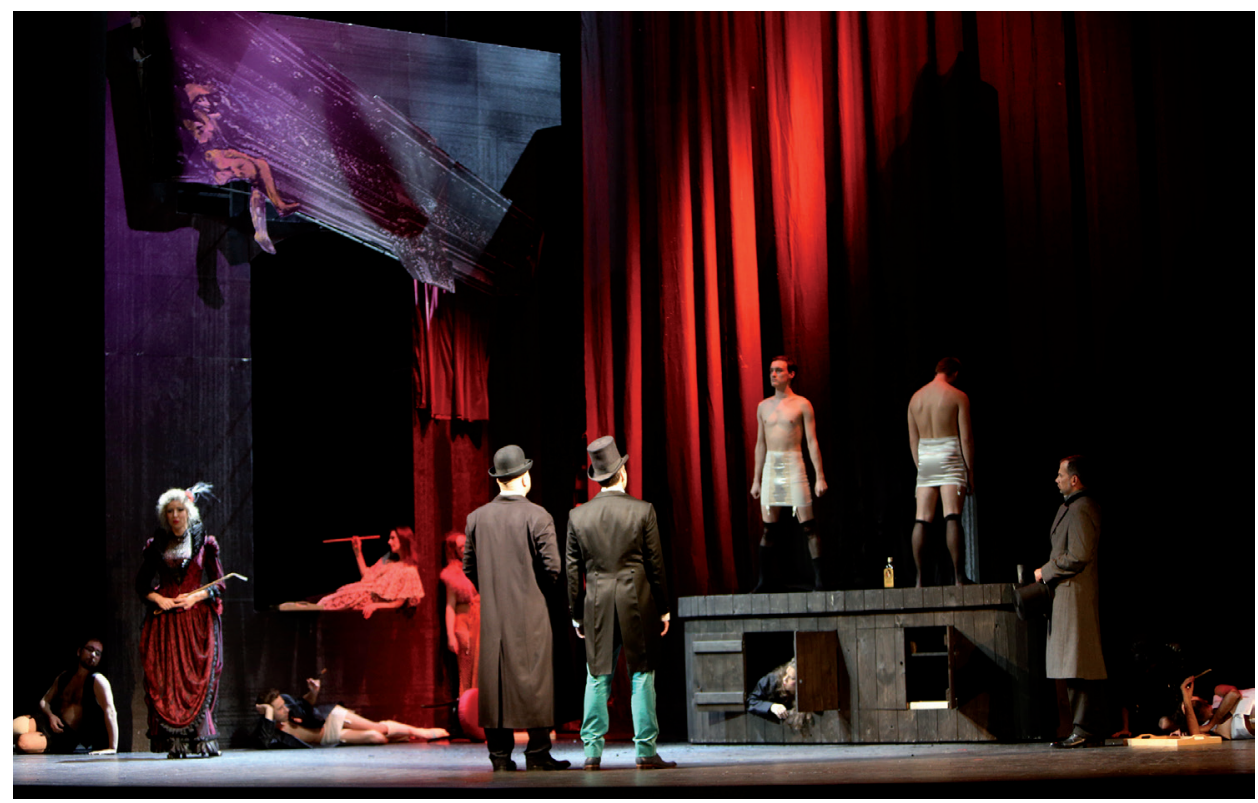

Obr. 9: Dorian Gray. Opera SND, 2013.

Zdroj: Archív SND

Foto: Jozef Barinka

SUMMARY

Dorian Gray and His Musical Portrait in the Eponymous Opera by Luubica Čekovská

The primary focus of the presented study is the identification of devices used for characters' description in the opera Dorian Gray by the composer L'ubica Čekovská and librettist Kate Pullinger. The first part of the study deals with the Irish writer Oscar Wilde's novel The Picture of Dorian Gray, on which the opera is based. It explains the results of the comparison of the opera libreto and its literary model. The second part of the study is dedicated to the characterization of the musical language and characters of the opera Dorian Gray. Last but not least the study focuses on the central theme of the opera - the Voices of the Picture.

\section{Keywords}

Oscar Wilde, novel The Picture of Dorian Gray, Lubica Čekovská, opera Dorian Gray, characters' description 